\title{
Rituximab Treatment and Long-term Outcome of Patients With Autoimmune Encephalitis
}

\author{
Real-world Evidence From the GENERATE Registry
}

Franziska S. Thaler, MD, Luise Zimmermann, MD, Stefan Kammermeier, MD, Christine Strippel, MD, Marius Ringelstein, MD, Andrea Kraft, MD, Kurt-Wolfram Sühs, MD, Jonathan Wickel, MD, Christian Geis, MD, Robert Markewitz, MD, Christian Urbanek, MD, Claudia Sommer, MD, Kathrin Doppler, MD, Loana Penner, Jan Lewerenz, MD, Rosa Rößling, MD, Carsten Finke, MD, Harald Prüss, MD, Nico Melzer, MD,

Klaus-Peter Wandinger, MD, Frank Leypoldt, MD, and Tania Kümpfel, MD, on behalf of the German Network for Research on Autoimmune Encephalitis (GENERATE)

Neurol Neuroimmunol Neuroinflamm 2021;8:e1088. doi:10.1212/NXI.0000000000001088

\section{Abstract}

\section{Background and Objectives}

To determine the real-world use of rituximab in autoimmune encephalitis (AE) and to correlate rituximab treatment with the long-term outcome.

\section{Methods}

Patients with NMDA receptor (NMDAR)-AE, leucine-rich glioma-inactivated-1 (LGI1)- AE, contactin-associated protein-like-2 (CASPR2)-AE, or glutamic acid decarboxylase 65 (GAD65) disease from the GErman Network for Research on AuToimmune Encephalitis who had received at least 1 rituximab dose and a control cohort of non-rituximab-treated patients were analyzed retrospectively.

\section{Results}

Of the 358 patients, 163 (46\%) received rituximab (NMDAR-AE: 57\%, CASPR2-AE: 44\%, LGI1-AE: 43\%, and GAD65 disease: $37 \%$ ). Rituximab treatment was initiated significantly earlier in NMDAR- and LGI1-AE (median: 54 and 155 days from disease onset) compared with CASPR2-AE or GAD65 disease (median: 632 and 1,209 days). Modified Rankin Scale (mRS) scores improved significantly in patients with NMDAR-AE, both with and without rituximab treatment. Although being more severely affected at baseline, rituximab-treated patients with NMDAR-AE more frequently reached independent living ( $\mathrm{mRS}$ score $\leq 2$ ) (94\% vs $88 \%$ ). In LGI1-AE, rituximab-treated and nontreated patients improved, whereas in CASPR2-AE, only rituximab-treated patients improved significantly. No improvement was observed in patients with GAD65 disease. A significant reduction of the relapse rate was observed in rituximab-treated patients ( $5 \%$ vs $13 \%)$. Detection of NMDAR antibodies was significantly associated with mRS score improvement. A favorable outcome was also observed with early treatment initiation.

\author{
Correspondence \\ Dr. Thaler \\ franziska.thaler@ \\ med.uni-muenchen.de
}

MORE ONLINE

(III) Class of Evidence Criteria for rating therapeutic and diagnostic studies

NPub.org/coe

\footnotetext{
From the Institute of Clinical Neuroimmunology (F.S.T., T.K.), University Hospital and Biomedical Center, Ludwig-Maximilians-Universität, Munich; Section of Translational Neuroimmunology (L.Z., J.W., C.G.), Department of Neurology, Jena University Hospital, Jena; Department of Neurology (S.K.), University Hospital, Ludwig-Maximilians-University, Munich; Department of Neurology with Institute of Translational Neurology (Christine Strippel, N.M.), University of Muenster; Department of Neurology (M.R., N.M.), Medical Faculty, Heinrich Heine University Düsseldorf; Department of Neurology (M.R.), Center for Neurology and Neuropsychiatry, LVR-Klinikum, Heinrich Heine University Düsseldorf; Department of Neurology Martha-Maria Hospital (A.K.), Halle/Saale, Academic Hospital of University Halle-Wittenberg; Department of Neurology (K.-W.S.), Hannover Medical School; Department of Neurology (R.M., K.-P.W.), University Hospital Schleswig-Holstein, Lübeck; Department of Neurology (C.U.), Klinikum der Stadt Ludwigshafen a. Rh. gGmbH, Ludwigshafen; Department of Neurology (C. Sommer, K.D.), University Hospital Würzburg; Department of Neurology (L.P., J.L.), Ulm University; Department of Neurology and Experimental Neurology (R.R., C.F., H.P.), Charité - Universitätsmedizin Berlin; German Center for Neurodegenerative Diseases (DZNE) Berlin (R.R., H.P.); Neuroimmunology Section (K.-P.W., F.L.), Institute of Clinical Chemistry, University Hospital Schleswig-Holstein Kiel, Lübeck; and Department of Neurology (F.L.), Christian-Albrechts-Universität Kiel, Germany.

Go to Neurology.org/NN for full disclosures. Funding information is provided the end of the article.

F. Leypoldt and T. Kümpfel contributed equally to this work as co-senior authors.
}

German Network for Research on Autoimmune Encephalitis (GENERATE) coinvestigators are listed in Appendix 2 at the end of the article.

The Article Processing Charge was funded by the authors.

This is an open access article distributed under the terms of the Creative Commons Attribution-NonCommercial-NoDerivatives License 4.0 (CC BY-NC-ND), which permits downloading and sharing the work provided it is properly cited. The work cannot be changed in any way or used commercially without permission from the journal. 


\section{Glossary}

abs = antibodies; $\mathbf{A E}=$ autoimmune encephalitis; $\mathbf{C A}=$ cerebellar ataxia; $\mathbf{C A S P R 2 ~ = ~ c o n t a c t i n - a s s o c i a t e d ~ p r o t e i n - l i k e - 2 ; ~ C B A ~ = ~}$ cell-based assay; GAD65 = glutamic acid decarboxylase 65; GENERATE = GErman Network for Research on AuToimmune Encephalitis; IHC = immunohistochemistry; IVIG = IV immunoglobulin; LE = limbic/autoimmune encephalitis; LGI1 = leucine-rich glioma-inactivated-1; mRS = Modified Rankin Scale; NMDAR = NMDA receptor; RIA = radioimmunoassay; SPS $=$ stiff-person syndrome.

\section{Discussion}

We provide real-world data on immunosuppressive treatments with a focus on rituximab treatment for patients with $\mathrm{AE}$ in Germany. We suggest that early and short-term rituximab therapy might be an effective and safe treatment option in most patients with NMDAR-, LGI1-, and CASPR2-AE.

\section{Class of Evidence}

This study provides Class IV evidence that rituximab is an effective treatment for some types of AE.

Autoimmune encephalitis $(\mathrm{AE})$ is an umbrella term for an emerging spectrum of immune-mediated neuropsychiatric disorders often associated with antibodies (abs) against neuronal cell surface, synaptic, or intracellular proteins. ${ }^{1,2}$ Anti-NMDA receptor (NMDAR)-AE, anti-leucine-rich glioma-inactivated-1 (LGI1)-AE, anti-contactin-associated protein-like-2 (CASPR2)$\mathrm{AE}$, and anti-glutamic acid decarboxylase-65 (GAD65) disease together make up the majority of seropositive $\mathrm{AE}$ subtypes. NMDAR-AE affects young adults and children with female preponderance, is frequently associated with ovarian teratomas, and causes psychiatric symptoms, movement disorders, decreased consciousness, autonomic dysregulation, epileptic seizures, and central apnea. ${ }^{3,4}$ LGI1-AE affects middle-aged or elderly patients, causes short-term memory deficits, confusion, and epileptic seizures, ${ }^{5,6}$ and is sometimes preceded by faciobrachial dystonic or tonic seizures. ${ }^{7}$ CASPR2-AE predominantly affects elderly men and causes encephalitis and neuromyotonia, neuropathic pain, ataxia, myoclonus, autonomic dysfunction, or a combination thereof (e.g., Morvan syndrome). ${ }^{8,9}$ GAD65 disease is considerably more heterogeneous, affects predominantly women of all ages, and may cause cerebellar ataxia (CA), limbic/AE (LE), stiff-person syndrome (SPS), isolated temporal lobe epilepsy, and overlap forms of the aforementioned manifestations. ${ }^{10-13}$

Early diagnosis and prompt initiation of immunotherapy is crucial and often leads to substantial or complete recovery from these severe disorders. ${ }^{8}$ However, treatment data from randomized trials are scarce. ${ }^{14,15}$ Empiric treatment of $\mathrm{AE}$ usually consists of a step-wise escalation of immunotherapy including first-line therapy with steroids, plasma exchange, IV immunoglobulin (IVIG), or combinations, followed by second-line therapy with cyclophosphamide, rituximab, or combinations. ${ }^{2}$ Rituximab is a B cell-depleting monoclonal ab directed against CD20 with established efficacy in many neurologic autoimmune diseases including $\mathrm{MS},{ }^{16}$ and neuromyelitis optica spectrum disorders. ${ }^{17}$ Rituximab was shown to be effective in $\mathrm{AE}$ associated with different auto-abs. ${ }^{4,18,19}$
By contrast, 1 randomized placebo-controlled trial with rituximab did not show efficacy in patients with SPS. ${ }^{15}$ Detailed and comparative evaluations of rituximab use and the longterm outcome between $\mathrm{AE}$ subtypes in a real-world setting are missing. In this study, we evaluated demographic and clinical characteristics, laboratory findings, and immunotherapies in patients with NMDAR-, LGI1-, CASPR2-AE, or GAD65 disease in a cohort from the GErman NEtwork for Research on AuToimmune Encephalitis (GENERATE) registry and compared patients who had received at least 1 rituximab dose with non-rituximab-treated patients. In the rituximab cohort, we specifically correlated early, high-dose, or prolonged rituximab treatment with the long-term outcome.

\section{Methods}

\section{Standard Protocol Approvals, Registrations, and Patient Consents}

All data were collected from the GENERATE registry, which is a noninterventional retrospective and prospective multicentric database for patients with AE in Germany, Austria, and Switzerland (generate-net.de). GENERATE was approved by the institutional review boards of all actively recruiting centers. Patients from participating centers entered into the registry until June 30, 2019, were analyzed. The study was performed according to the Declaration of Helsinki. All enrolled patients or their legal representatives gave written informed consent before enrollment in the registry.

\section{Study Population}

The following patients were included: (1) patients with detection of NMDAR-, LGI1-, CASPR2-, or GAD65 abs according to the ab criteria below; (2) clinical diagnosis of $\mathrm{AE}$ based on the consensus criteria published in reference 2 , or for patients with GAD abs, alternatively diagnosis of CA or SPS; (3) any documented treatment with rituximab; and (4) available information on the number, dosage, and timing of rituximab infusions. In addition, a control cohort with 
consistent inclusion criteria except for rituximab treatment was included.

\section{Analysis of Clinical, Laboratory, and Immunotherapy Profiles}

$\mathrm{Ab}$ testing was performed in the respective GENERATE centers using cell-based assays (CBAs) and confirmation by immunofluorescence (commercial test kit panels Euroimmun, Lübeck) and/or immunohistochemistry (IHC) for NMDAR, LGI1, and CASPR2, and ELISA, radioimmunoassay (RIA), or CBA for GAD65. Patients fulfilling the following $\mathrm{ab}$ criteria in earliest available samples were included: NMDAR abs detected in serum by CBA confirmed by IHC (in the absence of confirmatory IHC in serum, only CBA serum titers of $>1: 500$ were considered specific) and/or CSF positive; GAD abs $>1: 500$ in CBA or $>2000 I E / m L$ in ELISA or RIA in serum and/or CSF positive; LGI1 abs at any titer in CSF and/or serum; CASPR2 abs >1:128 in serum and/or CSF positive. ${ }^{20}$ Only IgG abs were considered relevant.

Data on any immunotherapy were recorded. First-line immunotherapy was defined as treatment with corticosteroids, plasma exchange/immunoabsorption, and IVIG; second-line therapy included rituximab in the rituximab cohort and all other immunotherapies except reapplied corticosteroids, IVIG, and plasma exchange in both cohorts. The occurrence of relapses during follow-up was based on the overall clinical impression of the treating physician. Functional status was assessed using the modified Rankin Scale (mRS) at the peak of disease and then throughout disease course. Side effects of rituximab treatment were queried from all participating centers.

\section{Primary Research Question}

Do rituximab-treated patients with NMDAR-AE, LGI1-AE, CASPR2-AE, and GAD65 disease have a better outcome than non-rituximab-treated patients?

\section{Classification of Evidence}

This study provides Class IV evidence that rituximab is an effective treatment for some types of $\mathrm{AE}$.

\section{Statistics}

Statistical tests were performed using Prism Software (GraphPad). Normality testing was performed using the D'Agostino-Pearson omnibus test. Continuous variables with $>2$ subgroups were compared using the Kruskal-Wallis test followed by the Dunn multiple comparisons test and with 2 subgroups using the Mann-Whitney test. Ordinal variables were compared using the $\chi^{2}$ test or the Fisher exact test. The Benjamini-Hochberg procedure was performed to control for multiple testing. Multivariate analysis was performed by ordinal logistic fit using JMP software (Version 16, JMP, A Business Unit of SAS, Cary, NC).

\section{Data Availability}

No deidentified patient data will be shared. No study-related documents will be shared. Reasonable requests from any qualified investigator for anonymized data will be considered by the corresponding author.

\section{Results}

\section{Patient Characteristics}

We identified 358 patients with NMDAR-AE, GAD65 disease, LGI1-AE, or CASPR2-AE. One hundred sixty-three patients (46\%) were treated with rituximab. Based on the inclusion criteria, 14 patients in the rituximab cohort and 32 patients in the control cohort were excluded from further analysis (Figure 1, eFigure 1, links.lww.com/NXI/A595). Our final study cohort comprised 149 patients in the rituximab cohort (NMDAR-AE: $\mathrm{n}=81$, GAD65 disease: $\mathrm{n}=31$, LGI1-AE: $\mathrm{n}=26$, and CASPR2AE: $\mathrm{n}=11$ ) and 163 patients in the control cohort (NMDARAE: $\mathrm{n}=61$, GAD65 disease: $\mathrm{n}=53$, LGI1-AE: $\mathrm{n}=35$, and CASPR2-AE: $\mathrm{n}=14$ ) (Figure 1). Overall, rituximab was administered most frequently in NMDAR-AE (57\%), followed by CASPR2-AE (44\%), LG1-1-AE (43\%), and GAD65 disease (37\%). Clinical characteristics as well as CSF and MRI parameters, as expected, varied considerably between the ab subgroups (Table 1). Differences between the rituximab cohort and the control cohort indicating severity bias were observed for patients with NMDAR-AE and GAD65 disease: patients with NMDAR$\mathrm{AE}$ treated with rituximab had a significantly higher $\mathrm{mRS}$ score at peak of disease (rituximab cohort: median: 4.0; control cohort: median: 3.0) and a significantly higher frequency of decreased consciousness (Table 1). In patients with GAD65 disease, the $\mathrm{mRS}$ score at the peak of disease was also higher in the rituximab cohort (median: 3.0 ) compared with the control cohort (median: 2.0) (Table 1).

\section{First-Line and Second-Line Treatments}

All patients with rituximab treatment received prior first-line immunotherapy. In the control cohort, 4 patients (7\%) with NMDAR-AE, 5 patients (9\%) with GAD65 disease, and 1 patient (7\%) with CASPR2-AE had no prior first-line immunotherapy (Table 2). Time to initiation of first-line therapy was shortest in patients with NMDAR-AE, and the therapy was started significantly earlier in patients with NMDAR-AE treated with rituximab (median: 16 days) compared with patients with NMDAR-AE not receiving rituximab (median: 33 days) (Table 2). In all subgroups, the majority of patients received a combination of different first-line treatments with steroids and plasma exchange being the most frequent combination in the overall cohort $(\mathrm{n}=103 ; 33 \%)$ (Figure $2, \mathrm{~A}-\mathrm{H})$. As expected, because of severity bias, patients in the rituximab cohort were treated significantly more often with combinations of first-line therapy (Figure 2, A-H). Physicians reported some improvement following first-line therapy in the majority of patients independent of the subgroup. Of interest, the frequency of this observation was similar between patients later receiving rituximab and patients who were treated differently (Table 2 ).

Forty patients (25\%) in the control cohort and 38 patients (26\%) in the rituximab cohort received a second-line immunotherapy 


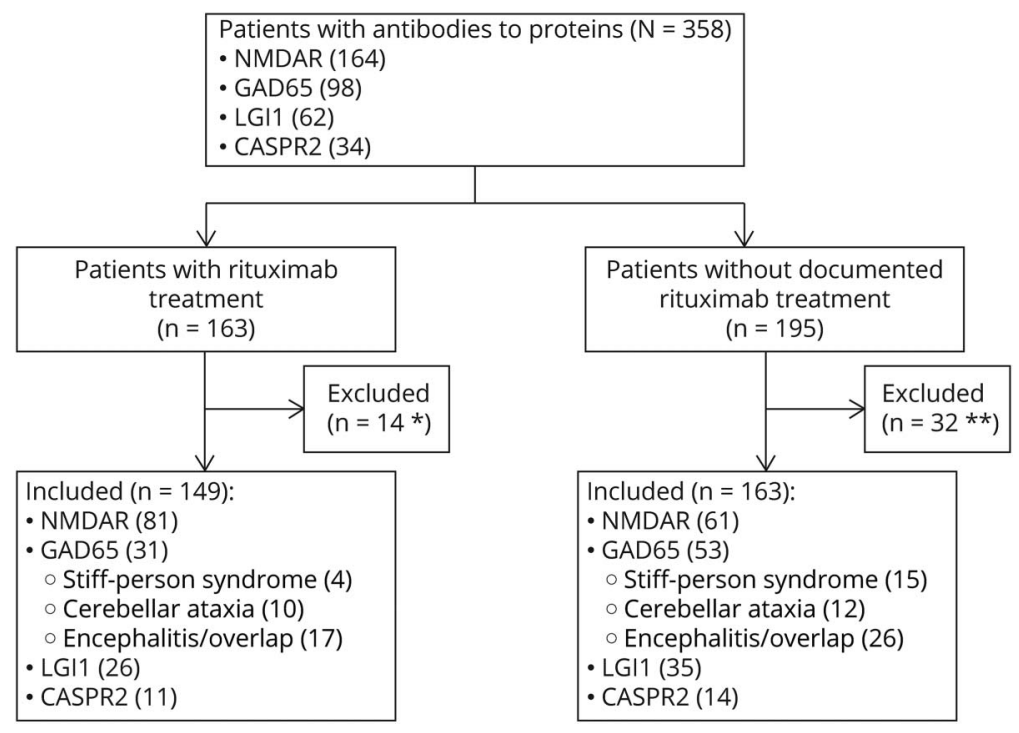

Patient numbers in the different study subpopulations are depicted. *Patients excluded because of insufficient data on rituximab dosing $(n=2)$, concomitant diagnosis of MS $(n=2)$, retraction of consent for the GENERATE registry $(n=1)$, or not fulfilling the $a b$ criteria for inclusion $(n=9)$. **Patients excluded because of insufficient data on immunosuppressive treatment $(n=1)$ or not fulfilling the ab criteria for inclusion ( $n$ = 31). CA, cerebellar ataxia; CASPR2 = contactin-associated protein-like-2; Enc. = encephalitis; GAD65 = glutamic acid decarboxylase 65; GENERATE = GErman Network for Research on AuToimmune Encephalitis; LGI1 = leucine-rich glioma-inactivated-1; NMDAR = NMDA receptor; SPS = stiffperson syndrome.

other than rituximab. The frequency of application of second-line immunotherapies other than rituximab did not differ between the rituximab cohort and the control cohort (Table 2). These second-line immunotherapies included cyclophosphamide, azathioprine, mycophenolate mofetil, methotrexate, bortezomib, daratumumab, tacrolimus, and basiliximab (Figure 2, I-P) and were applied before, parallel to, or after rituximab therapy. In patients with NMDAR-AE and GAD65 disease, more aggressive second-line therapies such as cyclophosphamide, bortezomib, or daratumumab were applied more frequently in the rituximab cohort compared with the control cohort (Figure 2, I-P). Other than this and the above-mentioned severity bias, we did not observe significant selection bias between patients treated with and without rituximab.

\section{Description of Rituximab Treatments}

A wide spectrum of rituximab treatment regimens was observed in our rituximab cohort. In detail, patients with GAD65 disease and CASPR2-AE received rituximab significantly later (GAD65: median 1,209 days, CASPR2: 632 days) than patients with NMDAR-AE (median: 54 days) and LGI1-AE (median: 155 days) (Figure 3A; Table 2). Time from initiation of first-line treatment to rituximab treatment was shortest in NMDAR-AE (median: 30 days) and longest in GAD65 disease (median: 141 days) (Figure 3B; Table 2). Sixteen (20\%) patients with NMDAR-AE received rituximab very early within 2 weeks after first-line immunotherapy. The median number of infusions and total rituximab dose did not differ significantly among the subgroups (Figure 3C, D; Table 2). The duration of rituximab treatment, defined as the time from first to last infusion, was shortest in NMDAR-AE (median: 24 days) and longest in GAD65 disease (median: 454 days) (Figure $3 \mathrm{E}$ and Table 2). The percentage of patients who received only induction therapy defined as time between first to last rituximab treatment of less than 6 months was highest in patients with NMDAR-AE (54\%) and lowest in patients with GAD65 abs (27\%); patients with LGI1- and CASPR2-AE were in between (35\% and 46\%, respectively) (Figure 3F; Table 2). Side effects after rituximab treatment were rare $(n=5,3.4 \%)$; however, they were not systematically registered in this study. In detail, we observed $n=2$ infusionrelated reactions $(\mathrm{n}=1$ : urticaria with, however, simultaneous IVIG application; $\mathrm{n}=1$ : tremor, tachycardia, and fear); $\mathrm{n}=1$ lymphopenia leading to a reduction of the rituximab dose; $n=$ 1 frequent infections; and $n=1$ unknown side effect.

\section{Follow-up and Treatment Response}

Follow-up data were available for 282 patients (90\%) with a median follow-up duration of 41 months with no significant differences between rituximab-treated patients and controls regarding follow-up data availability and duration (Table 2). The distribution of $\mathrm{mRS}$ scores at the peak of disease and at last follow-up improved significantly in patients with NMDAR-AE and in patients with LGI1-AE both in the rituximab cohort and in the control cohort. In patients with CASPR2-AE, a significant improvement was observed only in the rituximab cohort, but not in the control cohort. No significant improvement was observed in patients with GAD65 disease (Figure 3G). In addition, in patients with GAD65 disease, no significant improvement was observed when $\mathrm{mRS}$ scores were analyzed in the different disease subentities (encephalitis/overlap syndrome, CA, and SPS) (eFigure 2A, links.lww.com/NXI/A596).

Although patients with NMDAR-AE treated with rituximab were affected more severely at baseline (Table 1), at final follow-up, $94 \%$ of rituximab-treated patients compared with $88 \%$ of nontreated patients had reached independent living ( $\mathrm{mRS}$ score $\leq 2, p=0.33$ ). Patients with LGI1-AE reached independent living in $83 \%$ of cases treated with rituximab and 
Table 1 Characterization of the Patient Cohort

\begin{tabular}{|c|c|c|c|c|c|c|c|c|c|c|c|c|}
\hline & \multicolumn{3}{|l|}{ NMDAR } & \multicolumn{3}{|l|}{ GAD65 } & \multicolumn{3}{|l|}{ LGI1 } & \multicolumn{3}{|l|}{ CASPR2 } \\
\hline & $\begin{array}{l}\text { Ritux } \\
(n=81)\end{array}$ & $\begin{array}{l}\text { Ctrl } \\
(n=61)\end{array}$ & $p$ Value & $\begin{array}{l}\text { Ritux } \\
(n=31)\end{array}$ & $\begin{array}{l}\text { Ctrl } \\
(n=53)\end{array}$ & $p$ Value & $\begin{array}{l}\text { Ritux } \\
(n=26)\end{array}$ & $\begin{array}{l}\text { Ctrl } \\
(n=35)\end{array}$ & $p$ Value & $\begin{array}{l}\text { Ritux } \\
(n=11)\end{array}$ & $\begin{array}{l}\text { Ctrl } \\
(n=14)\end{array}$ & $p$ Value \\
\hline Female; n (\%) & $62(77)$ & $46(75)$ & $>0.99$ & $26(84)$ & $34(64)$ & 0.08 & $13(50)$ & $18(51)$ & $>0.99$ & $1(9)$ & $0(0)$ & 0.44 \\
\hline $\begin{array}{l}\text { Age at onset, y; mean } \\
(95 \% \mathrm{Cl})\end{array}$ & $28(25-31)$ & $32(28-36)$ & 0.20 & $46(40-53)$ & $51(47-55)$ & 0.27 & $61(55-66)$ & $63(59-67)$ & 0.46 & $66(60-72)$ & $69(63-75)$ & 0.40 \\
\hline \multicolumn{13}{|l|}{ Symptoms; n (\%) } \\
\hline Seizures & $57(70)$ & $34(56)$ & 0.08 & $14(45)$ & $24(45)$ & $>0.99$ & $17(65)$ & $25(71)$ & 0.78 & $7(64)$ & $10(71)$ & $>0.99$ \\
\hline Sensible deficits & $14(17)$ & $8(13)$ & 0.64 & $4(13)$ & $6(11)$ & $>0.99$ & $1(4)$ & $6(17)$ & 0.22 & $3(27)$ & $4(29)$ & $>0.99$ \\
\hline Decreased consciousness & $53(65)$ & $23(38)$ & 0.001 & $7(23)$ & $4(8)$ & 0.09 & $10(39)$ & $13(37)$ & $>0.99$ & $3(27)$ & $5(36)$ & $>0.99$ \\
\hline Psychiatric symptoms & $76(94)$ & $55(90)$ & 0.53 & $8(26)$ & $14(26)$ & $>0.99$ & $18(69)$ & $16(46)$ & 0.08 & $5(45)$ & $8(57)$ & 0.70 \\
\hline Autonomic dysfunction & $35(43)$ & $20(33)$ & 0.23 & $2(6)$ & $3(6)$ & $>0.99$ & $3(12)$ & $4(11)$ & $>0.99$ & $0(0)$ & $2(14)$ & 0.49 \\
\hline Movement disorder & $39(48)$ & $20(33)$ & 0.09 & $13(42)$ & $19(36)$ & 0.64 & $2(8)$ & $6(17)$ & 0.45 & $3(27)$ & $4(29)$ & $>0.99$ \\
\hline Paresis & $7(9)$ & $8(13)$ & 0.42 & $1(3)$ & $5(9)$ & 0.41 & $1(4)$ & $3(9)$ & 0.63 & $0(0)$ & $1(7)$ & $>0.99$ \\
\hline Cerebellar symptoms & $8(10)$ & $10(16)$ & 0.31 & $13(42)$ & $20(38)$ & 0.82 & $1(4)$ & $0(0)$ & 0.43 & $3(27)$ & $1(7)$ & 0.29 \\
\hline Brainstem symptoms & $16(20)$ & $14(23)$ & 0.68 & $9(29)$ & $12(23)$ & 0.60 & $1(4)$ & $2(6)$ & $>0.99$ & $1(9)$ & $0(0)$ & 0.44 \\
\hline Cognitive impairment & $69(85)$ & $47(77)$ & 0.28 & $13(42)$ & $28(53)$ & 0.37 & $23(88)$ & $29(83)$ & 0.72 & $10(91)$ & $10(71)$ & 0.34 \\
\hline ICU admission; n (\%) & $38(47)$ & $24(39)$ & 0.40 & $2(6)$ & $0(0)$ & 0.13 & $0(0)$ & $3(9)$ & 0.25 & $1(9)$ & $1(7)$ & $>0.99$ \\
\hline Tumor; n (\%) & 14 (17)a & $12(20)^{b}$ & 0.83 & $1(3)^{c}$ & $1(2)^{d}$ & $>0.99$ & $2(8)^{e}$ & $1(3)^{f}$ & 0.57 & $0(0)$ & $3(21)^{g}$ & 0.23 \\
\hline $\begin{array}{l}\text { mRS score worst status; } \\
\text { median (IQR) }\end{array}$ & $4(2)$ & $3(2)$ & 0.005 & $3(2)$ & $2(1)$ & 0.003 & $3(2)$ & $3(2)$ & 0.77 & $3(1)$ & $3(1.25)$ & 0.95 \\
\hline \multicolumn{13}{|l|}{ CSF/MRI profiles } \\
\hline CSF cc $\geq 5 / \mu \mathrm{L} ; \mathrm{n}(\%)$ & $61(73)$ & $41(67)$ & 0.35 & $7(23)$ & $6(11)$ & 0.22 & $4(15)$ & $3(9)$ & 0.45 & $7(64)$ & $3(21)$ & 0.05 \\
\hline CSF cc; median, (IQR) & $41(92)$ & $34(61)$ & 0.22 & $8(6)$ & $8(12)$ & 0.86 & $6(5)$ & $8(13)$ & 0.34 & $9(13)$ & $8(4)$ & 0.61 \\
\hline $\begin{array}{l}\text { CSF protein >0.45 mg/dL; } \\
\text { n (\%) }\end{array}$ & $24(30)$ & $20(33)$ & 0.72 & $10(32)$ & $25(47)$ & 0.25 & $9(35)$ & $11(31)$ & $>0.99$ & $8(73)$ & $10(71)$ & $>0.99$ \\
\hline Elev. protein; median (IQR) & $54(12)$ & $68(39)$ & 0.02 & $53(14)$ & $55(18)$ & 0.89 & $59(18)$ & $58(12)$ & $>0.99$ & $63(16)$ & $57(26)$ & 0.83 \\
\hline CSF-specific OCBs; n (\%) & $48(59)$ & $25(41)$ & 0.04 & $15(48)$ & $23(43)$ & 0.82 & $2(8)$ & $1(39)$ & 0.57 & $2(18)$ & $2(14)$ & $>0.99$ \\
\hline MRI abnormalities; n (\%) & $40(49)$ & $29(48)$ & 0.87 & $16(52)$ & $26(49)$ & $>0.99$ & $21(81)$ & $30(86)$ & 0.73 & $7(64)$ & $9(64)$ & $>0.99$ \\
\hline
\end{tabular}

Abbreviations: CASPR2 = contactin-associated protein-like 2; cc = cell count; Ctrl = controls; Elev. = elevated; GAD65 = glutamic acid decarboxylase 65; ICU = intensive care unit; IQR = interquartile range; Lgl1 = leucine-rich glioma-inactivated protein 1; mRS = Modified Rankin Scale; NMDAR = NMDA receptor; OCB = oligoclonal band; Ritux = Rituximab-treated patients.

a $14 x$ teratoma, ${ }^{\text {' }} 9 x$ teratoma, $2 x$ prostate cancer, $1 \times$ small-cell lung cancer, ${ }^{c} 1 x$ unknown tumor, ${ }^{d} 1 \times$ small-cell lung cancer, ${ }^{\mathrm{e}} 1 \mathrm{x}$ neuroendocrine tumor small intestine, $1 \times$ oligoastrocytoma, $1 \times$ mamma carcinoma, ${ }^{\mathrm{g}} 1 \mathrm{x}$ thymoma, $1 \mathrm{x}$ unclear pulmonal lesion and mediastinal lymphadenopathy, $1 \mathrm{x}$ prostate cancer.

Continuous variables were compared using the Mann-Whitney test, and categorical values were compared using the Fisher exact test. Unadjusted $p$-values are indicated.

$p$ Values reaching statistical significance after adjustment using the Benjamini-Hochberg procedure with a false discovery rate of $10 \%$ are indicated in bold.

in $78 \%$ of cases without rituximab treatment $(p=0.74)$. In CASPR2-AE, independent living was observed in $80 \%$ of cases treated with rituximab vs $57 \%$ of cases who did not receive $\mathrm{B}$-cell depletion $(p=0.60)$. In contrast, patients with GAD65 disease treated with rituximab, who were more severely affected at baseline, continued to have a lower rate of independent living compared with the non-rituximab-treated control cohort at last follow-up ( $52 \%$ vs $75 \%, p=0.07)$.

When we analyzed the mRS scores in the rituximab cohort throughout follow-up in more detail, we found patients with NMDAR-AE to improve significantly already before rituximab initiation (Figure 3, G.a I-II), presumably because of first-line treatments. After initiation of rituximab treatment, patients continued to improve significantly (Figure 3G.a II-III). No significant difference in the $\mathrm{mRS}$ score was observed in patients with NMDAR-AE exhibiting a tumor compared with those without a tumor both regarding $\mathrm{mRS}$ score at worst status and mRS score at last follow-up (eFigure 2B, links.lww.com/NXI/ A596). In LGI1 patients, a significant improvement was also already observed before rituximab treatment was initiated (Figure 3G.c I-II). After initiation of rituximab treatment, the $\mathrm{mRS}$ scores continued to drop; however, this improvement did not reach statistical significance (Figure 3G.c II-IV). In patients 
Table 2 Immunotherapy and Follow-up of Patients

\begin{tabular}{|c|c|c|c|c|c|c|c|c|c|c|c|c|}
\hline & \multicolumn{3}{|l|}{ NMDAR } & \multicolumn{3}{|l|}{ GAD65 } & \multicolumn{3}{|l|}{ LGI1 } & \multicolumn{3}{|l|}{ CASPR2 } \\
\hline & $\begin{array}{l}\text { Ritux } \\
(n=81)\end{array}$ & $\begin{array}{l}\text { Ctrl } \\
(n=61)\end{array}$ & $p$ Value & $\begin{array}{l}\text { Ritux } \\
(n=31)\end{array}$ & $\begin{array}{l}\text { Ctrl } \\
(n=53)\end{array}$ & $p$ Value & $\begin{array}{l}\text { Ritux } \\
(n=26)\end{array}$ & $\begin{array}{l}\text { Ctrl } \\
(n=35)\end{array}$ & $p$ Value & $\begin{array}{l}\text { Ritux } \\
(n=11)\end{array}$ & $\begin{array}{l}\text { Ctrl } \\
(n=14)\end{array}$ & $p$ Value \\
\hline \multicolumn{13}{|l|}{ Prior 1st-line immunotherapy } \\
\hline$n(\%)$ & $81(100)$ & $57(93)$ & 0.03 & $31(100)$ & $48(91)$ & 0.15 & $26(100)$ & $35(100)$ & $>0.99$ & $11(100)$ & $13(93)$ & $>0.99$ \\
\hline Time to 1 st line ${ }^{a}, d$; median (IQR) & $16(33)$ & $33(93)$ & 0.0009 & $466(1,306)$ & $1,040(1856)$ & 0.31 & $52(185)$ & $43(168)$ & 0.38 & $149(741)$ & $157(414)$ & 0.87 \\
\hline Response to 1 st line $e^{b} ; n / n(\%)$ & $40 / 55(73)$ & $38 / 43(88)$ & 0.08 & $22 / 26(85)$ & $24 / 30(80)$ & 0.74 & $14 / 16(88)$ & $27 / 27(100)$ & 0.13 & $4 / 5(80)$ & $8 / 8(100)$ & 0.38 \\
\hline \multicolumn{13}{|l|}{ Rituximab treatment } \\
\hline Time to therapya, d; median (IQR) & $54(200)$ & I & I & $\begin{array}{l}1,209 \\
(2,331)\end{array}$ & I & I & $155(192)$ & I & l & $632(722)$ & I & l \\
\hline Time from 1st line, d; median (IQR) & $30(105)$ & l & I & 141 (544) & I & I & $47(127)$ & l & I & $67(190)$ & I & I \\
\hline No. of infusions, $n$; median (IQR) & $3(1)$ & I & I & $4(6)$ & I & I & $3.5(1.5)$ & I & I & $4(3)$ & I & I \\
\hline Cumulative dose, g; median (IQR) & $2.6(2.0)$ & l & I & $3.5(4.0)$ & I & I & $3.0(2.0)$ & I & l & $3.0(2.5)$ & I & l \\
\hline Dose/infusion, g; median (IQR) & $1.0(0.3)$ & I & I & $1.0(0.3)$ & I & I & $1.0(0.02)$ & I & I & $1.0(0)$ & I & l \\
\hline 1st to last infusion, d; median (IQR) & $24(491)$ & l & I & $454(1,116)$ & I & I & $227(484)$ & I & I & $203(490)$ & I & I \\
\hline Induction only (<6 mo); n (\%) & $44(54)$ & I & I & $8(27)$ & I & I & $9(35)$ & I & I & $5(46)$ & I & I \\
\hline \multicolumn{13}{|l|}{ Other 2nd-line immunotherapy ${ }^{c}$} \\
\hline$n(\%)$ & $20(25)$ & $11(18)$ & 0.41 & $13(42)$ & $11(21)$ & 0.05 & $4(15)$ & $14(40)$ & 0.05 & $1(9)$ & $4(29)$ & 0.34 \\
\hline \multicolumn{13}{|l|}{ Follow-up (FU) } \\
\hline FU data available, $n$ (\%) & $68(84)$ & $56(92)$ & 0.21 & $30(97)$ & $48(91)$ & 0.41 & $25(96)$ & $32(91)$ & 0.63 & $9(82)$ & $14(100)$ & 0.18 \\
\hline Duration, mo; median (IQR) & $35(44)$ & $26(39)$ & 0.26 & $72(97)$ & $72(87)$ & 0.68 & $40(27)$ & $31(42)$ & 0.17 & $39(24)$ & $34(40)$ & 0.87 \\
\hline mRS score $\leq 2$ at last FU; $n(\%)$ & $48(94)$ & $49(88)$ & 0.33 & $14(52)$ & $36(75)$ & 0.07 & $20(83)$ & $25(78)$ & 0.74 & $4(80)$ & $8(57)$ & 0.60 \\
\hline Relapse during FU; $\mathbf{n}(\%)$ & $13(19)^{d}$ & $7(13)$ & 0.34 & $\rho^{\mathrm{e}}$ & I & / & $5(20)$ & $10(31)^{f}$ & 0.40 & $1(11)$ & $2(14)$ & $>0.99$ \\
\hline \multirow[t]{4}{*}{ Timing of relapse; $\mathbf{n}$} & $<1$ y: 4 & $<1 \mathrm{y}: 1$ & I & 1 & 1 & 1 & $<1 \mathrm{y}: 1$ & $<1 \mathrm{y}: 5^{f}$ & / & $<1$ y: 0 & $<1 \mathrm{y}: 0$ & 1 \\
\hline & $1-2 y: 4^{d}$ & $1-2 y: 4$ & 1 & 1 & 1 & 1 & $1-2 y: 1$ & $1-2 y: 2^{f}$ & I & $1-2 y: 1$ & $1-2 \mathrm{y}: 0$ & 1 \\
\hline & $2-5 y: 4$ & $2-5$ y: 2 & I & l & I & I & $2-5 y: 3$ & $2-5 y: 3$ & I & $2-5 y: 0$ & $2-5$ y: 2 & / \\
\hline & $>5 \mathrm{y}: 1$ day & $>5 \mathrm{y}: 0$ & ' & I & I & I & $>5 \mathrm{y}: 0$ & $>5 \mathrm{y}: 0$ & ' & $>5 \mathrm{y}: 0$ & $>5 \mathrm{y}: 0$ & ' \\
\hline $\begin{array}{l}\text { Relapse after rituximab } \\
\text { treatment, } n(\%)\end{array}$ & $3(4)^{g}$ & I & $0.18^{h}$ & 1 & I & 1 & $3(12)^{g}$ & 1 & $0.12^{h}$ & $0(0)$ & I & $0.50^{h}$ \\
\hline
\end{tabular}

Abbreviations: CASPR2 = contactin-associated protein-like 2; FU = follow-up; GAD65 = glutamic acid decarboxylase 65; IQR = interquartile range; LgI1 = leucinerich glioma-inactivated protein $1 ; \mathrm{mRS}=$ modified Rankin Scale; NMDAR = NMDA receptor.

${ }^{a}$ From symptom onset; ${ }^{\text {b }}$ calculated for the proportion of patients for whom information regarding response to 1 st-line immunotherapy was available 'except rituximab, corticosteroids, and PLEX; ${ }^{\mathrm{d}} 1$ patient experienced relapses both after $1-2 \mathrm{y}$ and $>5 \mathrm{y}$ from disease onset; ${ }^{\text {in }}$ in patients with GAD abs, chronic worsening rather than clear relapses is observed; ${ }^{\mathrm{f}} 1$ patient experienced relapses both after $<1$ y and after $1-2 \mathrm{y}$; ${ }^{\mathrm{g}} \mathrm{NMDA}$-AE: 1 relapse occurred 3 mo after initiation of rituximab, 1 relapse occurred 1 y and 8 mo after last rituximab infusion, 1 relapse occurred during continued rituximab treatment with yearly infusions; LGI1-AE: 1 relapse occurred 6 mo after last rituximab infusion, 1 relapse occurred under low-dose rituximab treatment with application of $100 \mathrm{mg}$ every $6 \mathrm{mo}, 1$ relapse occurred $2 \mathrm{y}$ and $8 \mathrm{mo}$ after last rituximab infusion. ${ }^{\mathrm{h}} \mathrm{Comparison}$ with the relapse rate in the control cohort.

Continuous variables were compared using the Mann-Whitney test, and categorical values were compared using the Fisher exact test.

Unadjusted $p$ values are indicated. $p$ Values reaching statistical significance after adjustment using the Benjamini-Hochberg procedure with a false discovery rate of $10 \%$ are indicated in bold.

with CASPR2-AE, mRS scores decreased after initiation of rituximab treatment (Figure 3G.d II-IV) without reaching significance presumably because of small patient numbers.

Nineteen relapses (14\%) were reported during follow-up in the rituximab cohort (NMDAR-AE: $\mathrm{n}=13,19 \%$; LGI1-AE: $\mathrm{n}=5$, 20\%; and CASPR2-AE: $\mathrm{n}=1,11 \%$ ). Of note, only 6 relapses $(5 \%)$ in the rituximab cohort occurred after rituximab treatment was started (NDMAR-AE: $\mathrm{n}=3,4 \%$; LGI1-AE: $\mathrm{n}=3$;
12\%) (Table 2). The other 13 relapses occurred before rituximab initiation. In the control cohort, 19 relapses (13\%) occurred (NMDAR-AE: $\mathrm{n}=7,13 \%$; LGI1-AE: $\mathrm{n}=10,31 \%$; CASPR2-AE: $\mathrm{n}=2,14 \%$ ), which was more frequent than those observed in the rituximab group after initiation of rituximab $(p=0.02)($ Table 2$)$.

Finally, we performed a multivariate analysis for the rituximab cohort to identify factors associated with the extent of 


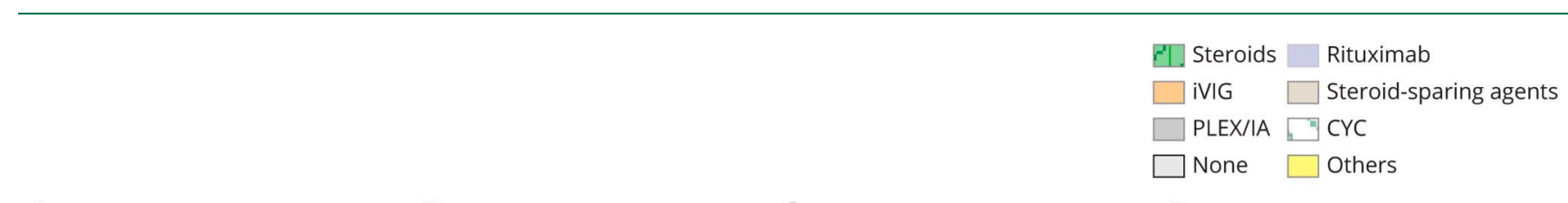
A. $\operatorname{NMDAR}(n=81)$
B. $\operatorname{GAD} 65(n=31)$
C. LG|1 $(n=26)$
D. CASPR2 $(n=11)$

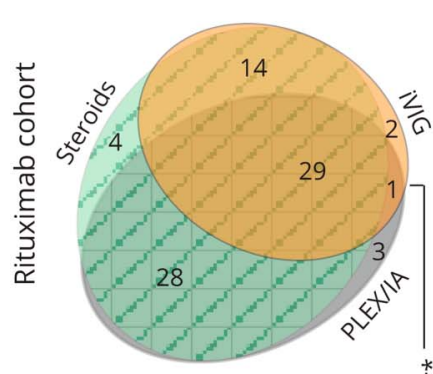

E. $\operatorname{NMDAR}(n=61)$

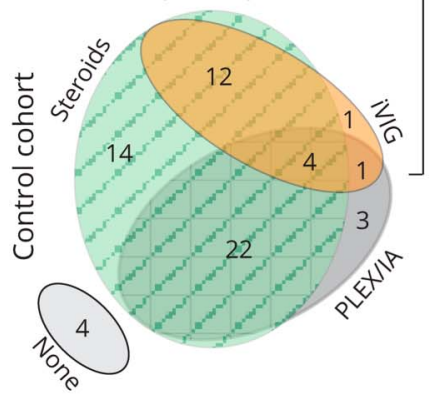

I. $\operatorname{NMDAR}(n=81)$

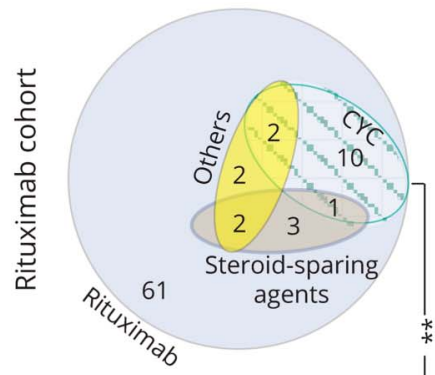

M. NMDAR $(n=61) \quad$ CYC

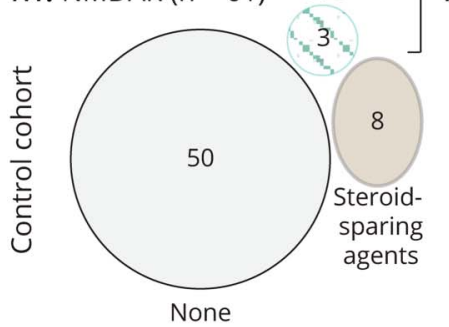

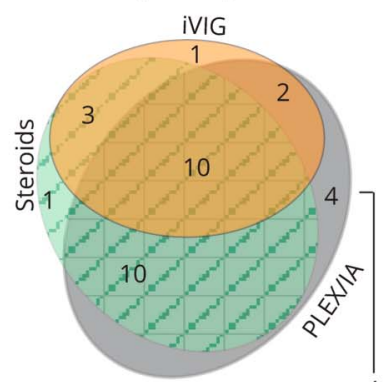

F. GAD65 ( $n=53)$

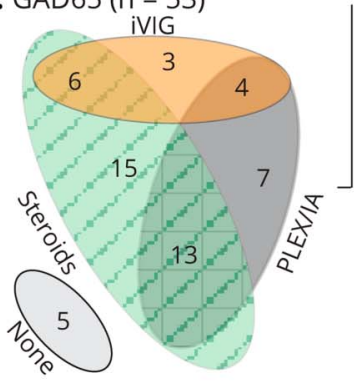

J. $\operatorname{GAD} 65(n=31)$

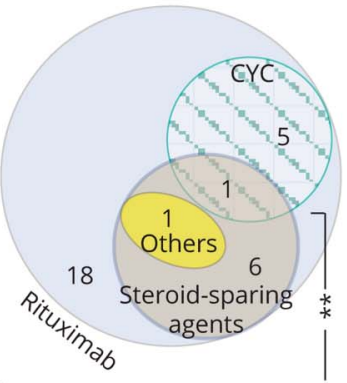

N. GAD65 ( $n=53)$

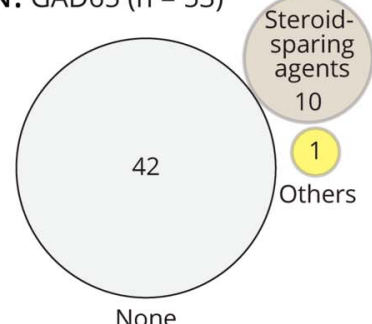

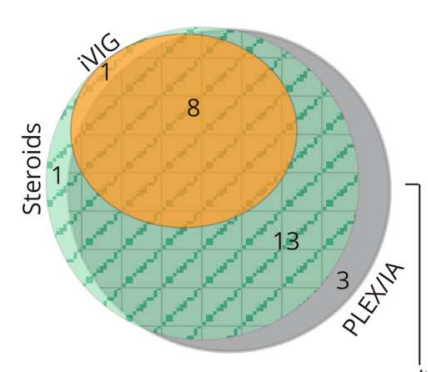

G. LGI1 $(n=35)$

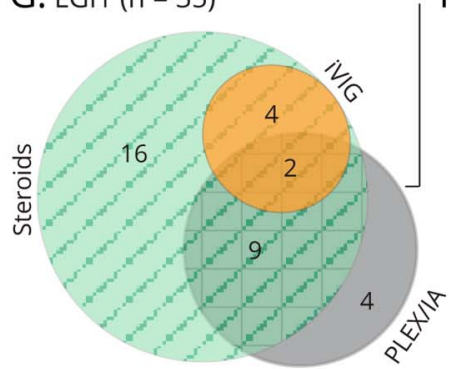

H. CASPR2 $(n=14)$
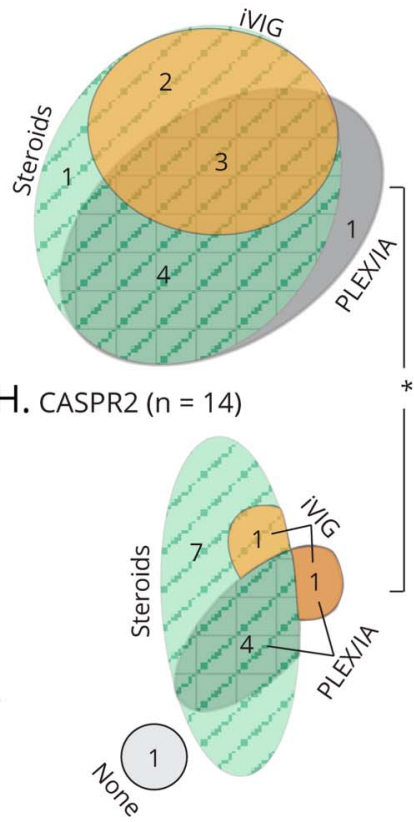

K. LGI1 $(n=26)$

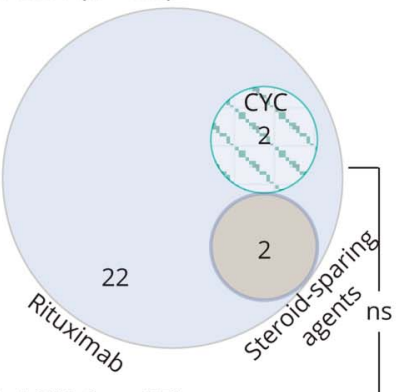

O. LGI1 ( $(n=35) \quad C Y C$

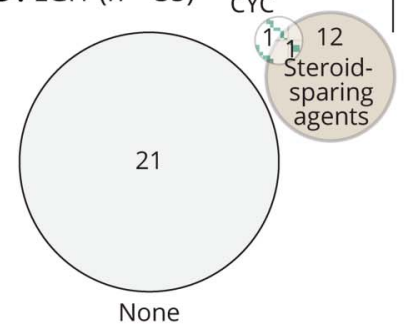

L. CASPR2 $(n=11)$

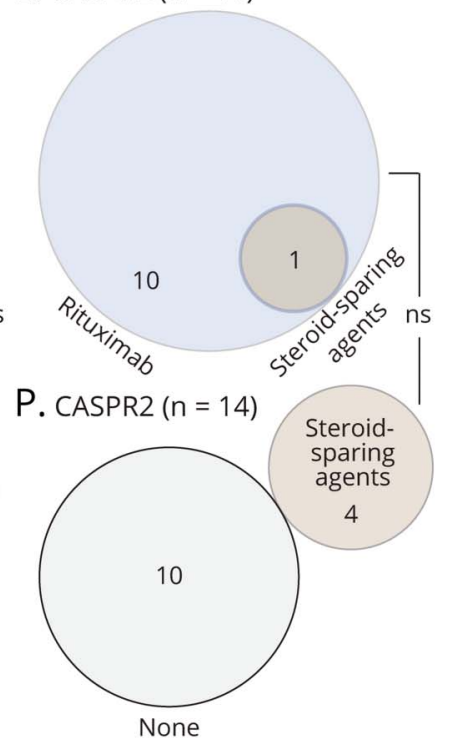

The numbers of patients treated with the respective prior first-line immunotherapies $(A-H)$ and second-line immunotherapies (I-P) in the rituximab cohort (A-D) and in the control cohort (E-H) are depicted for the different ab subgroups (A, E, I, and M: NMDAR-AE; B, F, J, and N: GAD65 disease; C, G, K, and O: LGI1$\mathrm{AE}$; and $\mathrm{D}, \mathrm{H}, \mathrm{L}$, and P: CASPR2-AE). Other second-line therapies included bortezomib ( $\mathrm{n}=6$ in patients with NMDAR-AE treated with rituximab), daratumumab ( $n=1$ in patients with NMDAR-AE treated with rituximab), tacrolimus ( $n=1$ in patients with GAD65 disease treated with rituximab and $n=1$ in patients with GAD65 disease not treated with rituximab), and basiliximab ( $n=1$ in patients with GAD65 disease treated with rituximab). Areas of Venn diagrams are proportional to the case numbers relative to the respective subgroup. (A-H) Proportions of combination first-line therapy relative to none/monotherapy were compared using the Fisher exact test. $* \star \star p<0.001$, $* * p<0.01$, and $* p<0.05$. (I-P) Proportions of treatment with cyclophosphamide or other therapies relative to steroid-sparing therapies and no treatment were compared using the Fisher exact test. $* \star \star * p<0.001, * \star p<0.01$, and ${ }^{*} p<0.05$. AZA $=$ azathioprine; CASPR2 = contactin-associated protein-like-2; cyc = cyclophosphamide; GAD65 = glutamic acid decarboxylase 65; IVIG = IV immunoglobulin; MMF = mycophenolate mofetil; MTX = methotrexate; NMDAR = NMDA receptor; LGI1 = leucine-rich glioma-inactivated-1; PLEX = plasma exchange.

improvement as measured by the change in the mRS score from baseline to last follow-up. Most significantly, the $\mathrm{AE}$ subtype (NMDAR-AE) was associated with mRS score improvement, whereas rituximab dosage and duration were not significantly associated with an improved $\mathrm{mRS}$ score (Table 3 ). MRS score improvement was also observed for early initiation 
A
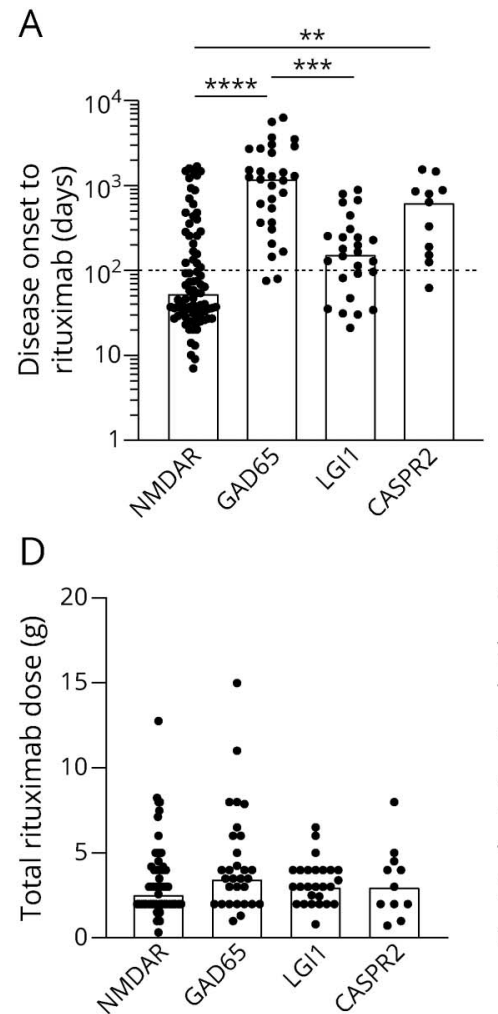

G.a NMDAR

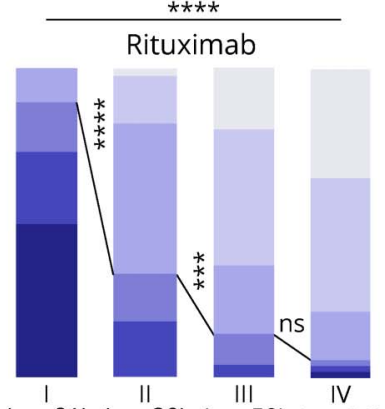

$(\mathrm{n}=81)(\mathrm{n}=39)(\mathrm{n}=50)(\mathrm{n}=51)$

G.C LGI1

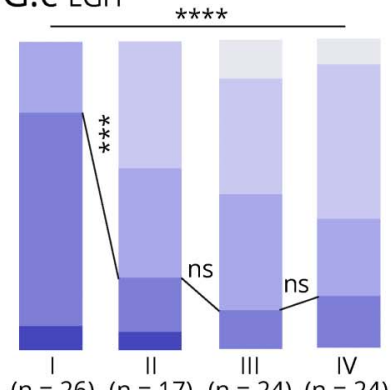

$(n=26)(n=17)(n=24)(n=24)$
$\mathrm{B}$

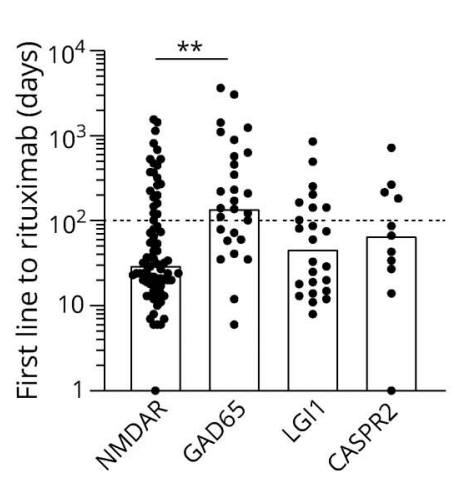

$\mathrm{E}$

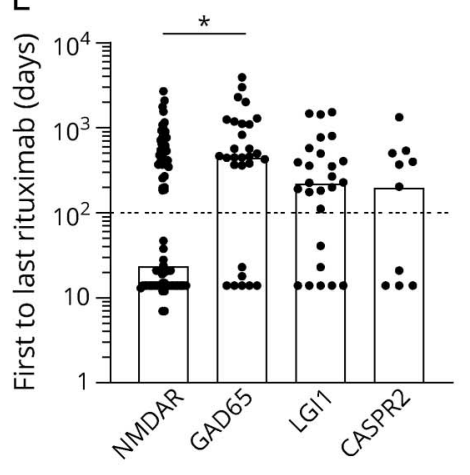

G.b GAD65

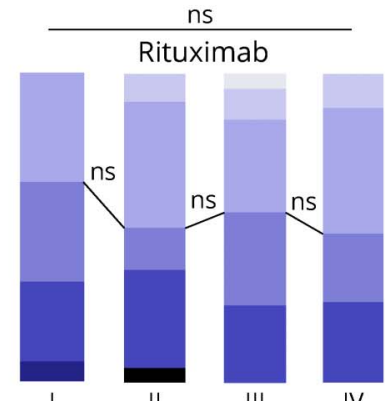

$(n=31) \quad(n=22)(n=20)(n=27)$

G.d CASPR2

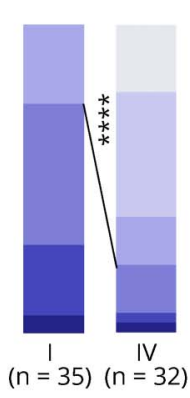

$(n=35)(n=32)$

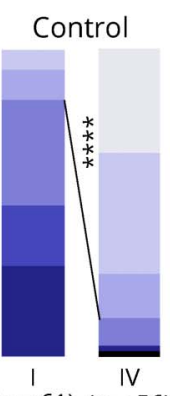

$(n=61)(n=56)$

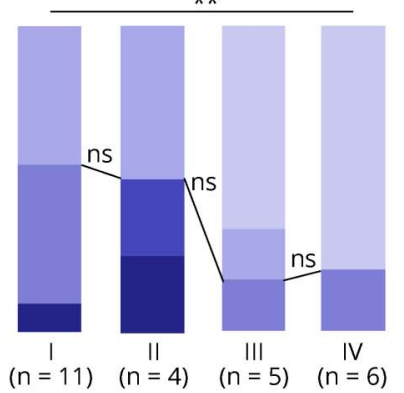

C

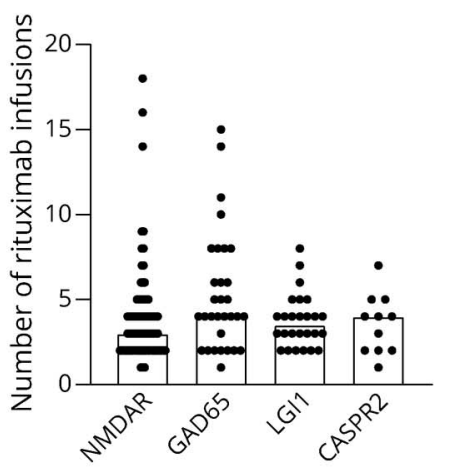

$\mathrm{F}$

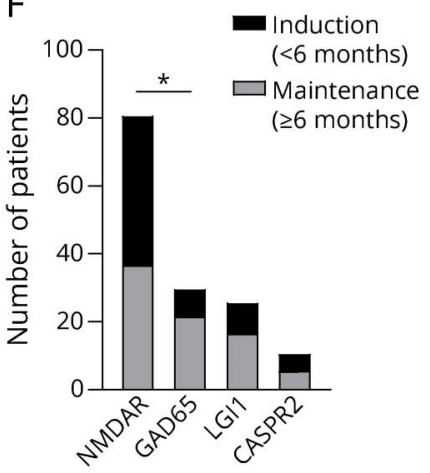

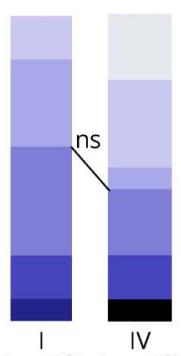

$(n=53)(n=48)$

(A-F) In different subgroups (NMDAR-AE, GAD65 disease, LGI1-AE, and CASPR2-AE), the duration in days from disease onset to initiation of rituximab treatment (A), the duration in days from initiation of first-line therapy to initiation of rituximab treatment $(B)$, the number of rituximab infusions (C), the total cumulative rituximab dose (D), the duration in days from the first to the last rituximab infusion (E), and the number of patients receiving induction therapy (rituximab treatment $<6$ months) or induction + maintenance therapy (rituximab treatment $\geq 6$ months) (F) are depicted. Bars indicate the median. Normality testing was performed using the D'AgostinoPearson omnibus test. Continuous variables were compared using the Kruskal-Wallis test followed by the Dunn multiple comparisons test, and ordinal variables were compared using the Fisher exact test. ${ }^{* * *} p<0.0001 * \star \star p<0.001, * \star p<0.01$, and $* p<0.05$. (G) mRS scores in the different ab subgroups were compared in the rituximab cohort and in the control cohort. The distribution of mRS scores is depicted at 4 time points: I, maximal mRS at symptom onset; II, mRS at initiation of rituximab treatment (from -2 months to +4 months from rituximab onset); III, mRS 4-12 months after initiation of rituximab treatment; IV, mRS at last follow-up with at least $>12$ months after rituximab treatment. The line represents the change in mRS scores dividing favorable mRS scores $(0-2)$ and nonfavorable $m R S$ scores $(\geq 3)$. The ordinal $\chi^{2}$ test was applied to compare the distribution of mRS scores. ${ }^{* \star *} p<0.0001 * * \star p<0.001$, ${ }^{* \star} p<0.01$, and ${ }^{*} p<0.05$. CASPR2, contactin-associated proteinlike-2; GAD65 = glutamic acid decarboxylase 65; mRS = modified Rankin Scale; NMDAR = NMDA receptor; LGI1 = leucine-rich glioma-inactivated-1. 
Table 3 Multivariate Analysis of the Outcome

\begin{tabular}{|c|c|c|c|c|}
\hline $\begin{array}{l}\text { Parameters analyzed for an effect } \\
\text { on outcome improvement ( } \Delta \text { mRs) }\end{array}$ & & & & \\
\hline Parameter & $p$ Value & DF & $\mathbf{R R}$ & $95 \% \mathrm{Cl}$ \\
\hline Antibody type & $<0.0001 *$ & 3 & & \\
\hline GAD65 vs NMDAR & & & 0.46 & $0.28-0.75$ \\
\hline LGI1 vs NMDAR & & & 0.84 & $0.34-1.46$ \\
\hline CASPR2 vs NMDAR & & & 0.70 & $0.52-1.39$ \\
\hline $\begin{array}{l}\text { Time from } 1 \text { st-line therapy } \\
\text { to rituximab initiation (d) }\end{array}$ & 0.02 & 1 & & \\
\hline$\leq 60$ vs $>60$ & & & 1.45 & $1.05-1.97$ \\
\hline $\begin{array}{l}\text { Time to 1st-line therapy } \\
\text { after symptom onset (d) }\end{array}$ & 0.04 & 1 & & \\
\hline$\leq 30$ vs $>30$ & & & 1.35 & $1.01-1.80$ \\
\hline No. of rituximab infusions ( $n$ ) & 0.05 & 2 & & \\
\hline $3-5$ vs $0-2$ & & & 2.2 & $0.99-5.00$ \\
\hline$\geq 6$ vs $3-5$ & & & 0.43 & $0.17-1.08$ \\
\hline $\begin{array}{l}\text { Time to rituximab initiation } \\
\text { after symptom onset (d) }\end{array}$ & 0.12 & 1 & & \\
\hline$\leq 90$ vs $>90$ & & & 0.73 & $0.48-1.09$ \\
\hline Age (y) & 0.44 & 3 & & \\
\hline$>20-40$ vs $0-20$ & & & 0.86 & $0.45-1.67$ \\
\hline$>40-60$ vs $>20-40$ & & & 0.69 & $0.35-1.35$ \\
\hline$>60$ vs $>40-60$ & & & 0.89 & $0.45-1.73$ \\
\hline Total rituximab dosage (g) & 0.464 & 2 & & \\
\hline$>2-5$ vs $0-2$ & & & 0.63 & $0.27-1.43$ \\
\hline$>5$ vs $>2-5$ & & & 1.51 & $0.55-4.48$ \\
\hline $\begin{array}{l}\text { Duration of rituximab } \\
\text { treatment }(\mathrm{mo}) \text { : }\end{array}$ & 0.48 & 1 & & \\
\hline$<6$ vs $\geq 6$ & & & 0.88 & $0.61-1.30$ \\
\hline Sex & 0.7086 & 1 & & \\
\hline F vs $M$ & & & 0.95 & $0.73-1.24$ \\
\hline $\begin{array}{l}\text { Abbreviations: CASPR2 = contactin-ass } \\
\text { freedom; GAD65 = glutamic acid deca } \\
\text { oma-inactivated protein } 1 ; \text { NMDAR }= \\
\text { Unadjusted } p \text { values are indicated. } p \text { V } \\
\text { after adjustment using the Benjamin } \\
\text { discovery rate of } 10 \% \text { are indicated in }\end{array}$ & $\begin{array}{l}\text { ciated prote } \\
\text { boxylase } 65 \\
\text { MDA recept } \\
\text { lues reachir } \\
\text { i-Hochberg } \\
\text { jold. }\end{array}$ & $\begin{array}{l}\text { In-like } \\
\text {; Lgl1 } \\
\text { or; RR } \\
\text { g sta } \\
\text { proce }\end{array}$ & $\begin{array}{l}2 \text {; DF } \\
=\text { leuci } \\
=\text { relat } \\
\text { istical s } \\
\text { dure w }\end{array}$ & $\begin{array}{l}\text { degrees of } \\
\text { ne-rich gli- } \\
\text { ive risk. } \\
\text { ignificance } \\
\text { ith a false }\end{array}$ \\
\hline
\end{tabular}

of rituximab treatment ( $\leq 60$ days after initiation of first-line treatment), and a trend was observed for early initiation of firstline treatment ( $\leq 30$ days after symptom onset).

\section{Discussion}

This study describes real-world data on rituximab usage in a large German cohort of patients with the most common $\mathrm{AE}$ subtypes. We confirm the following: (1) Rituximab is the most frequent second-line immunotherapy that is used in nearly half of all patients with $\mathrm{AE}$ in Germany. (2) Rituximab usage differs within AE subtypes with patients with NMDAR-AE most frequently and patients with GAD65 disease least frequently receiving rituximab. Treatment was in all cases initiated following prior first-line immunotherapy. Patients with NMDAR-AE and GAD65 disease were more likely to be treated with rituximab if they presented with more severe disease (decreased levels of consciousness and higher mRS). (3) Patients with NMDAR-AE were treated earlier and more often (54\%) received a short-term rituximab treatment ( $<6$ months) without repeated maintenance reinfusion than other AE subgroups. (4) The long-term outcome in patients with NMDAR-, LGI1-, and CASPR2-AE in the overall cohort was favorable with $91 \%, 80 \%$, and $63 \%$ of the patients being able to function independently at last follow-up, respectively. (5) Although comparison of patients with and without rituximab treatment is prone to severity bias, we found some hints of a better outcome and fewer relapses in the former group: patients with NMDAR-AE treated with rituximab more often reached independent living at last follow-up although being affected more severely at baseline; patients with CASPR2$\mathrm{AE}$ improved significantly better under rituximab treatment; patients with NMDAR-E and LGI1-AE experienced fewer relapses if treated with rituximab. (6) No significant improvement during follow-up of patients with GAD65 disease was observed both in the rituximab cohort and in the control cohort. However, although we did not observe a group effect in GAD65 disease, some individuals showed a remarkable response associated with B cell-depleting treatment.

In NMDAR-AE, treatment with rituximab is widely accepted. It has been used empirically since the first description of NMDAR$\mathrm{AE}$, and a large prospective case series ${ }^{4}$ and a systematic review ${ }^{21}$ could add further evidence that early second-line immunotherapy in patients not responding sufficiently to first-line immunotherapy was associated with better outcomes and fewer relapses. Recently, a meta-analysis of 14 retrospective and prospective case series summarizing 277 patients with AE (88.8\% NMDAR-AE) concluded that rituximab is an effective second-line agent with an acceptable toxicity profile. ${ }^{19}$ Our data confirm and extend these observations. We found patients with NMDAR-AE treated with rituximab to have a favorable outcome. As patients treated with induction or maintenance therapy did not significantly differ in the outcome, our data support the notion that in many patients with NMDAR-AE, short-term rituximab treatment might be sufficient to control the disease. In a recent position paper by the Autoimmune Encephalitis Alliance Clinicians Network, ${ }^{22}$ this is reflected by the recommendation to consider long-term rituximab treatment mainly in relapsing disease.

Compared with NMDAR-AE, considerably less information on long-term immunosuppression and especially rituximab is available in other AE subtypes. For LGI1-AE, early initiation of any immune therapy was associated with better outcomes in studies with $29^{7}$ and 13 patients, ${ }^{23}$ respectively. Only few patients were treated with rituximab in retrospective case 
series $^{19,24,25}$ and a small open-label trial. ${ }^{26}$ In our cohort, we observed a surprisingly favorable outcome in patients with LGI1-AE, with $80 \%$ reaching independent living ( $\mathrm{mRS}$ score $\leq 2$ ) ( $83 \%$ in the rituximab cohort and $78 \%$ in the control cohort). A systematic review ${ }^{21}$ showed full recovery or an mRS score of 0 in $27.8 \%$ of patients, with $8 \%$ of patients treated with rituximab and $18 \%$ of patients receiving secondline treatment. In light of these findings, we believe that rituximab treatment can be considered early in patients with LGI1-AE as 1 possible immunosuppressive treatment, although the duration of therapy is unclear.

Relapses occurred in $16 \%$ of patients with NMDAR-AE and $26 \%$ with LGI1-AE in our overall cohort. Previously, relapses were reported in $11.2 \%$ (85/758) of patients with NMDAR-AE and $18.8 \%(16 / 85)$ with LGI1-AE. ${ }^{21}$ However, we did observe a reduced rate of relapses in patients with NMDAR-AE and LGI1-AE treated with rituximab compared with patients without (independent of other second-line immunotherapies) suggesting better efficacy of rituximab in preventing relapses compared with other regimens. Nevertheless, this should be interpreted with caution because absolute patient numbers are small and controlled studies missing.

For the treatment of CASPR2-AE, even less evidence exists. In our series, $44 \%$ of patients with CASPR2-AE $(n=11)$ were treated with rituximab albeit considerably later than patients with NMDAR-AE. We could show significant improvement in patients with CASPR2-AE treated with rituximab, which was not observed in the control group. Although patient numbers were small, our results suggest an effect of rituximab treatment in CASPR2-AE but also indicate the need for larger numbers.

Immunotherapeutic strategies for GAD65-AE remain highly controversial. $^{27}$ Most patients are considered to require immunotherapy, and early immunotherapy has been found to be associated with a better outcome. ${ }^{10,28}$ However, the different neurologic manifestations of SPS, CA, and LE appear to respond differently to treatments. ${ }^{27}$ Treatment of SPS with IVIG has been examined in a small crossover placebo-controlled trial in 16 patients with SPS $^{11}$ and showed efficacy in approximately $80 \%$ of patients. The use of plasma exchange and corticosteroids was linked to ambiguous clinical responses, ${ }^{29,30}$ and immunosuppressive agents such as azathioprine, methotrexate, cyclophosphamide, and mycophenolate mofetil are currently used in clinical practice, however, with insufficient evidence from larger clinical trials. ${ }^{30,31}$ Rituximab was examined in a randomized, placebo-controlled trial in 24 patients with GAD65-SPS yet surprisingly did not show significant effects, possibly because of the long disease duration at the time of treatment initiation (8.0 years). ${ }^{15}$ The long-term outcome in SPS in general was poor, with $40 \%$ of patients not responding to immunotherapy. ${ }^{32} \mathrm{Al}$ though small case series show a benefit from immunotherapy including rituximab in GAD65-CA in $41 \%-48 \%$ of cases, ${ }^{33,34}$ the long-term outcome is poor in approximately $65 \%$ of patients. ${ }^{10}$ Similarly, most patients with GAD65-LE continue to have seizures with or without immunotherapy. ${ }^{35,36}$ Our data are in line with these observations. Rituximab treatment was initiated very late after onset of symptoms in our patients, and we did not find a significant association with a better outcome in these patients. Yet, the functional level was better than expected with $67 \%$ of patients being able to live independently ( $\mathrm{mRS}$ score $\leq 2)$ ( $52 \%$ in the rituximab group and $75 \%$ in the control group). In summary, our data support the notion that longstanding GAD65 disease does not respond to rituximab therapy. However, patients in early disease stages might be more likely to respond to rituximab treatment; however, response is difficult to predict, and a lack of response should trigger benefit-risk reevaluation of rituximab therapy.

We analyzed data acquired by the GENERATE network, a multicenter registry for $\mathrm{AE}$ in Germany. Of note, all participating centers had experience in treatment of $\mathrm{AE}$, and thus, our study is not necessarily representative for nonexpert centers or centers outside Germany. Further limitations of our study are the observational character going along with a severity bias when patients with and without rituximab treatment are compared and the difficulty to differentiate rituximab treatment effects from spontaneous improvements or improvements due to concomitant treatments, the incomplete follow-up data with potential selection bias, and the lack of clinical criteria defining response to first-line therapies. Nevertheless, because randomized trials are difficult to conduct in rare diseases such as $\mathrm{AE}$, real-world data from registries add important information on treatment profiles and sequences and may lead to standardized treatment protocols. In addition, single-center bias is unlikely due to the multicenter approach. Analysis of auto-ab levels, B-cell counts, and biomarkers like serum neurofilament light chain concentration throughout treatment course could add to future studies investigating the response to rituximab treatment in AE. In addition, safety data should be captured systematically.

Our results support the efficacy of early rituximab treatment in NMDAR-, LGI1-, and CASPR2-AE and suggest that shortterm therapy could be a treatment option. They also suggest that patients with long-standing GAD65 disease are less likely to benefit from $\mathrm{B}$-cell depletion than the other AE subgroups. Nevertheless, future controlled, randomized, and prospective studies in addition to national and supranational registries with collaborative research efforts are in dire need in the field of AE. As an example of such collaborative research, the multicentric, double-blinded, and placebo-controlled phase II study GENERATE-BOOST is currently investigating the response to bortezomib in patients with severe $\mathrm{AE}$.

\section{Acknowledgment}

The authors thank the patients and relatives contributing by donating their pseudonymized data and biomaterials to the GENERATE network.

\section{Study Funding}

This work was supported by the Else Kröner Fresenius Stiftung (2011_A154), the Gemeinnützige Hertie Stiftung, the Bundesministerium für Bildung und Forschung (CONNECT- 
GENERATE, 01GM1908), and the Munich Cluster for Systems Neurology (SyNergy).

\section{Disclosure}

The authors report no disclosures relevant to the manuscript. Go to Neurology.org/NN for full disclosures.

\section{Publication History}

Received by Neurology: Neuroimmunology \& Neuroinflammation February 12, 2021. Accepted in final form August 23, 2021.

\section{Appendix 1 Authors}

\begin{tabular}{|c|c|c|}
\hline Name & Location & Contribution \\
\hline $\begin{array}{l}\text { Franziska S. } \\
\text { Thaler, MD }\end{array}$ & $\begin{array}{l}\text { Institute of Clinical } \\
\text { Neuroimmunology, } \\
\text { University Hospital and } \\
\text { Biomedical Center, Ludwig- } \\
\text { Maximilians-University, } \\
\text { Munich, Germany }\end{array}$ & $\begin{array}{l}\text { Patient care, design of the } \\
\text { study, data analysis, } \\
\text { statistical analysis, and } \\
\text { paper writing }\end{array}$ \\
\hline
\end{tabular}

\begin{tabular}{|c|c|c|}
\hline $\begin{array}{l}\text { Luise } \\
\text { Zimmermann, } \\
\text { MD }\end{array}$ & $\begin{array}{l}\text { Section of Translational } \\
\text { Neuroimmunology, } \\
\text { Department of Neurology, } \\
\text { Jena University Hospital, } \\
\text { Germany }\end{array}$ & $\begin{array}{l}\text { Patient care, data analysis, } \\
\text { and revised the manuscript } \\
\text { for intellectual content }\end{array}$ \\
\hline $\begin{array}{l}\text { Stefan } \\
\text { Kammermeier, } \\
\text { MD }\end{array}$ & $\begin{array}{l}\text { Department of Neurology, } \\
\text { University Hospital, } \\
\text { Ludwig-Maximilians- } \\
\text { University, Munich, } \\
\text { Germany }\end{array}$ & $\begin{array}{l}\text { Statistical analysis and } \\
\text { revised the manuscript for } \\
\text { intellectual content }\end{array}$ \\
\hline $\begin{array}{l}\text { Christine } \\
\text { Strippel, MD }\end{array}$ & $\begin{array}{l}\text { Department of Neurology } \\
\text { with Institute of } \\
\text { Translational Neurology, } \\
\text { University of Muenster, } \\
\text { Germany }\end{array}$ & $\begin{array}{l}\text { Patient care, data analysis, } \\
\text { and revised the manuscript } \\
\text { for intellectual content }\end{array}$ \\
\hline $\begin{array}{l}\text { Marius } \\
\text { Ringelstein, MD }\end{array}$ & $\begin{array}{l}\text { Department of Neurology, } \\
\text { Medical Faculty, Heinrich } \\
\text { Heine University } \\
\text { Düsseldorf, Germany; } \\
\text { Department of Neurology, } \\
\text { Center for Neurology and } \\
\text { Neuropsychiatry, LVR- } \\
\text { Klinikum, Heinrich Heine } \\
\text { University Düsseldorf, } \\
\text { Germany }\end{array}$ & $\begin{array}{l}\text { Patient care, data analysis, } \\
\text { and revised the manuscript } \\
\text { for intellectual content }\end{array}$ \\
\hline $\begin{array}{l}\text { Andrea Kraft, } \\
\text { MD }\end{array}$ & $\begin{array}{l}\text { Department of Neurology } \\
\text { Martha-Maria Hospital, } \\
\text { Halle/Saale, Academic } \\
\text { Hospital of University } \\
\text { Halle-Wittenberg, } \\
\text { Germany }\end{array}$ & $\begin{array}{l}\text { Patient care, data analysis, } \\
\text { and revised the manuscript } \\
\text { for intellectual content }\end{array}$ \\
\hline $\begin{array}{l}\text { Kurt-Wolfram } \\
\text { Sühs, MD }\end{array}$ & $\begin{array}{l}\text { Department of Neurology, } \\
\text { Hannover Medical School, } \\
\text { Hannover, Germany }\end{array}$ & $\begin{array}{l}\text { Patient care, data analysis, } \\
\text { and revised the manuscript } \\
\text { for intellectual content }\end{array}$ \\
\hline $\begin{array}{l}\text { Jonathan } \\
\text { Wickel, MD }\end{array}$ & $\begin{array}{l}\text { Section of Translational } \\
\text { Neuroimmunology, } \\
\text { Department of Neurology, } \\
\text { Jena University Hospital, } \\
\text { Germany }\end{array}$ & $\begin{array}{l}\text { Patient care, data analysis, } \\
\text { and revised the manuscript } \\
\text { for intellectual content }\end{array}$ \\
\hline $\begin{array}{l}\text { Christian Geis, } \\
\text { MD }\end{array}$ & $\begin{array}{l}\text { Section of Translational } \\
\text { Neuroimmunology, } \\
\text { Department of Neurology, } \\
\text { Jena University Hospital, } \\
\text { Germany }\end{array}$ & $\begin{array}{l}\text { Patient care, data analysis, } \\
\text { and revised the manuscript } \\
\text { for intellectual content }\end{array}$ \\
\hline
\end{tabular}

Appendix 1 (continued)

\begin{tabular}{|c|c|c|}
\hline Name & Location & Contribution \\
\hline $\begin{array}{l}\text { Robert } \\
\text { Markewitz, MD }\end{array}$ & $\begin{array}{l}\text { Department of Neurology, } \\
\text { University Hospital } \\
\text { Schleswig-Holstein, } \\
\text { Lübeck, Germany }\end{array}$ & $\begin{array}{l}\text { Patient care, data analysis, } \\
\text { and revised the manuscript } \\
\text { for intellectual content }\end{array}$ \\
\hline $\begin{array}{l}\text { Christian } \\
\text { Urbanek, MD }\end{array}$ & $\begin{array}{l}\text { Department of } \\
\text { Neurology, Klinikum } \\
\text { der Stadt Ludwigshafen } \\
\text { a. Rh. gGmbH, } \\
\text { Germany }\end{array}$ & $\begin{array}{l}\text { Patient care, data } \\
\text { analysis, and revised the } \\
\text { manuscript for intellectual } \\
\text { content }\end{array}$ \\
\hline $\begin{array}{l}\text { Claudia } \\
\text { Sommer, MD }\end{array}$ & $\begin{array}{l}\text { Department of Neurology, } \\
\text { University Hospital } \\
\text { Würzburg, Germany }\end{array}$ & $\begin{array}{l}\text { Patient care, data } \\
\text { analysis, and revised the } \\
\text { manuscript for intellectual } \\
\text { content }\end{array}$ \\
\hline $\begin{array}{l}\text { Kathrin } \\
\text { Doppler, MD }\end{array}$ & $\begin{array}{l}\text { Department of Neurology, } \\
\text { University Hospital } \\
\text { Würzburg, Germany }\end{array}$ & $\begin{array}{l}\text { Patient care, data } \\
\text { analysis, and revised the } \\
\text { manuscript for intellectual } \\
\text { content }\end{array}$ \\
\hline Loana Penner & $\begin{array}{l}\text { Department of Neurology, } \\
\text { Ulm University, Germany }\end{array}$ & $\begin{array}{l}\text { Data analysis and revised } \\
\text { the manuscript for } \\
\text { intellectual content }\end{array}$ \\
\hline $\begin{array}{l}\text { Jan Lewerenz, } \\
\text { MD }\end{array}$ & $\begin{array}{l}\text { Department of Neurology, } \\
\text { Ulm University, Germany }\end{array}$ & $\begin{array}{l}\text { Patient care, data } \\
\text { analysis, and revised the } \\
\text { manuscript for intellectual } \\
\text { content }\end{array}$ \\
\hline $\begin{array}{l}\text { Rosa Rößling, } \\
\text { MD }\end{array}$ & $\begin{array}{l}\text { Department of Neurology } \\
\text { and Experimental } \\
\text { Neurology, Charité - } \\
\text { Universitätsmedizin } \\
\text { Berlin, Germany; } \\
\text { German Center for } \\
\text { Neurodegenerative } \\
\text { Diseases (DZNE) Berlin, } \\
\text { Germany }\end{array}$ & $\begin{array}{l}\text { Patient care, data analysis, } \\
\text { and revised the manuscript } \\
\text { for intellectual content }\end{array}$ \\
\hline
\end{tabular}

\begin{tabular}{lll}
\hline Carsten Finke, & $\begin{array}{l}\text { Department of Neurology } \\
\text { and Experimental }\end{array}$ & $\begin{array}{l}\text { Patient care, data analysis, } \\
\text { and revised the manuscript } \\
\text { Neurology, Charité - }\end{array}$ \\
& $\begin{array}{l}\text { Universitätsmedizin Berlin, } \\
\text { Germany }\end{array}$ & \\
&
\end{tabular}

Harald Prüss, Department of Neurology Patient care, data analysis, MD and Experimental and revised the manuscript Neurology, Charité - for intellectual content Universitätsmedizin Berlin Germany; German Center for Neurodegenerative Diseases (DZNE) Berlin, Germany

\begin{tabular}{|c|c|c|}
\hline $\begin{array}{l}\text { Nico Melzer, } \\
\text { MD }\end{array}$ & $\begin{array}{l}\text { Department of Neurology } \\
\text { with Institute of } \\
\text { Translational Neurology, } \\
\text { University of Muenster, } \\
\text { Germany; Department } \\
\text { of Neurology, Medical } \\
\text { Faculty, Heinrich Heine } \\
\text { University Düsseldorf, } \\
\text { Germany }\end{array}$ & $\begin{array}{l}\text { Patient care, data analysis, } \\
\text { and revised the manuscript } \\
\text { for intellectual content }\end{array}$ \\
\hline $\begin{array}{l}\text { Klaus-Peter } \\
\text { Wandinger, MD }\end{array}$ & $\begin{array}{l}\text { Department of Neurology, } \\
\text { University Hospital } \\
\text { Schleswig-Holstein, } \\
\text { Lübeck, Germany; } \\
\text { Neuroimmunology section, } \\
\text { Institute of Clinical } \\
\text { Chemistry, University } \\
\text { Hospital Schleswig- } \\
\text { Holstein Kiel, Lübeck, } \\
\text { Germany }\end{array}$ & $\begin{array}{l}\text { Patient care, data analysis, } \\
\text { and revised the manuscript } \\
\text { for intellectual content }\end{array}$ \\
\hline
\end{tabular}


Appendix 1 (continued)

\begin{tabular}{|c|c|c|}
\hline Name & Location & Contribution \\
\hline $\begin{array}{l}\text { Frank Leypoldt, } \\
\text { MD }\end{array}$ & $\begin{array}{l}\text { Neuroimmunology } \\
\text { Section, Institute of Clinical } \\
\text { Chemistry, University } \\
\text { Hospital Schleswig- } \\
\text { Holstein Kiel/Lübeck, } \\
\text { Germany; Department of } \\
\text { Neurology, Christian- } \\
\text { Albrechts-Universität Kiel, } \\
\text { Germany }\end{array}$ & $\begin{array}{l}\text { Patient care, design of the } \\
\text { study, data analysis, and } \\
\text { paper writing }\end{array}$ \\
\hline $\begin{array}{l}\text { Tania Kümpfel, } \\
\text { MD }\end{array}$ & $\begin{array}{l}\text { Institute of Clinical } \\
\text { Neuroimmunology, } \\
\text { University Hospital and } \\
\text { Biomedical Center, Ludwig- } \\
\text { Maximilians-University, } \\
\text { Munich, Germany }\end{array}$ & $\begin{array}{l}\text { Patient care, design of the } \\
\text { study, data analysis, and } \\
\text { paper writing }\end{array}$ \\
\hline
\end{tabular}

Appendix 2 Coinvestigators

\begin{tabular}{|c|c|c|c|}
\hline Name & Location & Role & Contribution \\
\hline $\begin{array}{l}\text { Michael } \\
\text { Adelmann, MD }\end{array}$ & $\begin{array}{l}\text { Vitos Weil-Lahn, Clinic for } \\
\text { Neurology, Weilmünster, } \\
\text { Germany }\end{array}$ & $\begin{array}{l}\text { Site } \\
\text { investigator }\end{array}$ & $\begin{array}{l}\text { Contributor } \\
\text { to the } \\
\text { GENERATE } \\
\text { registry }\end{array}$ \\
\hline $\begin{array}{l}\text { Luise } \\
\text { Appeltshauser, } \\
\text { MD }\end{array}$ & $\begin{array}{l}\text { Department of Neurology, } \\
\text { University Hospital } \\
\text { Würzburg, Würzburg, } \\
\text { Germany }\end{array}$ & $\begin{array}{l}\text { Site } \\
\text { investigator }\end{array}$ & $\begin{array}{l}\text { Contributor } \\
\text { to the } \\
\text { GENERATE } \\
\text { registry }\end{array}$ \\
\hline $\begin{array}{l}\text { Ilya Ayzenberg, } \\
\text { MD }\end{array}$ & $\begin{array}{l}\text { Department of Neurology, } \\
\text { St. Josef Hospital, Ruhr } \\
\text { University Bochum, } \\
\text { Bochum, Germany }\end{array}$ & $\begin{array}{l}\text { Site } \\
\text { investigator }\end{array}$ & $\begin{array}{l}\text { Contributor } \\
\text { to the } \\
\text { GENERATE } \\
\text { registry }\end{array}$ \\
\hline $\begin{array}{l}\text { Carolin Baade- } \\
\text { Büttner, MD }\end{array}$ & $\begin{array}{l}\text { Department of Neurology, } \\
\text { Jena University Hospital, } \\
\text { Germany }\end{array}$ & $\begin{array}{l}\text { Site } \\
\text { investigator }\end{array}$ & $\begin{array}{l}\text { Contributor } \\
\text { to the } \\
\text { GENERATE } \\
\text { registry }\end{array}$ \\
\hline $\begin{array}{l}\text { Andreas van } \\
\text { Baalen, MD }\end{array}$ & $\begin{array}{l}\text { Clinic for Child and } \\
\text { Adolescent Medicine II, } \\
\text { University Hospital } \\
\text { Schleswig-Holstein, Kiel, } \\
\text { Germany }\end{array}$ & $\begin{array}{l}\text { Site } \\
\text { investigator }\end{array}$ & $\begin{array}{l}\text { Contributor } \\
\text { to the } \\
\text { GENERATE } \\
\text { registry }\end{array}$ \\
\hline $\begin{array}{l}\text { Sebastian } \\
\text { Baatz, MD }\end{array}$ & $\begin{array}{l}\text { Department of Neurology, } \\
\text { Klinikum Altenburger Land } \\
\text { GmbH, Altenburg, } \\
\text { Germany }\end{array}$ & $\begin{array}{l}\text { Site } \\
\text { investigator }\end{array}$ & $\begin{array}{l}\text { Contributor } \\
\text { to the } \\
\text { GENERATE } \\
\text { registry }\end{array}$ \\
\hline $\begin{array}{l}\text { Bettina Balint, } \\
\text { MD }\end{array}$ & $\begin{array}{l}\text { Department of Neurology, } \\
\text { University Hospital, } \\
\text { Heidelberg, Germany }\end{array}$ & $\begin{array}{l}\text { Site } \\
\text { investigator }\end{array}$ & $\begin{array}{l}\text { Contributor } \\
\text { to the } \\
\text { GENERATE } \\
\text { registry }\end{array}$ \\
\hline $\begin{array}{l}\text { Sebastian } \\
\text { Bauer, MD }\end{array}$ & $\begin{array}{l}\text { Epilepsy Center Frankfurt } \\
\text { Rhine-Main and } \\
\text { Department of Neurology, } \\
\text { Goethe University } \\
\text { Frankfurt, Frankfurt am } \\
\text { Main, Germany }\end{array}$ & $\begin{array}{l}\text { Site } \\
\text { investigator }\end{array}$ & $\begin{array}{l}\text { Contributor } \\
\text { to the } \\
\text { GENERATE } \\
\text { registry }\end{array}$ \\
\hline $\begin{array}{l}\text { Annette } \\
\text { Baumgartner, } \\
\text { MD }\end{array}$ & $\begin{array}{l}\text { Department of Neurology, } \\
\text { Medical Center, University } \\
\text { of Freiburg, Faculty of } \\
\text { Medicine, University of } \\
\text { Freiburg, Freiburg, } \\
\text { Germany }\end{array}$ & $\begin{array}{l}\text { Site } \\
\text { investigator }\end{array}$ & $\begin{array}{l}\text { Contributor } \\
\text { to the } \\
\text { GENERATE } \\
\text { registry }\end{array}$ \\
\hline
\end{tabular}

Appendix 2 (continued)

\begin{tabular}{|c|c|c|c|}
\hline Name & Location & Role & Contribution \\
\hline $\begin{array}{l}\text { Sonka Benesch, } \\
\text { MD }\end{array}$ & $\begin{array}{l}\text { Department of Neurology, } \\
\text { Klinikum Aschaffenburg- } \\
\text { Alzenau, Germany }\end{array}$ & $\begin{array}{l}\text { Site } \\
\text { investigator }\end{array}$ & $\begin{array}{l}\text { Contributor } \\
\text { to the } \\
\text { GENERATE } \\
\text { registry }\end{array}$ \\
\hline $\begin{array}{l}\text { Robert Berger, } \\
\text { MD }\end{array}$ & $\begin{array}{l}\text { Department of } \\
\text { Neurology, ASKLEPIOS } \\
\text { Klinik Hamburg Altona, } \\
\text { Hamburg, Germany }\end{array}$ & $\begin{array}{l}\text { Site } \\
\text { investigator }\end{array}$ & $\begin{array}{l}\text { Contributor } \\
\text { to the } \\
\text { GENERATE } \\
\text { registry }\end{array}$ \\
\hline $\begin{array}{l}\text { Sascha Berning, } \\
\text { MD }\end{array}$ & $\begin{array}{l}\text { Department of Neurology, } \\
\text { Klinikum Osnabrück, } \\
\text { Osnabrück, Germany }\end{array}$ & $\begin{array}{l}\text { Site } \\
\text { investigator }\end{array}$ & $\begin{array}{l}\text { Contributor } \\
\text { to the } \\
\text { GENERATE } \\
\text { registry }\end{array}$ \\
\hline $\begin{array}{l}\text { Sarah Bernsen, } \\
\text { MD }\end{array}$ & $\begin{array}{l}\text { Department of } \\
\text { Neurodegenerative } \\
\text { Disoders, University of } \\
\text { Bonn, Germany }\end{array}$ & $\begin{array}{l}\text { Site } \\
\text { investigator }\end{array}$ & $\begin{array}{l}\text { Contributor } \\
\text { to the } \\
\text { GENERATE } \\
\text { registry }\end{array}$ \\
\hline $\begin{array}{l}\text { Christian Bien, } \\
\text { MD }\end{array}$ & $\begin{array}{l}\text { Bethel Epilepsy Center, } \\
\text { Mara Hospital, Bielefeld, } \\
\text { Germany }\end{array}$ & $\begin{array}{l}\text { Site } \\
\text { investigator }\end{array}$ & $\begin{array}{l}\text { Contributor } \\
\text { to the } \\
\text { GENERATE } \\
\text { registry }\end{array}$ \\
\hline $\begin{array}{l}\text { Corinna Bien, } \\
\text { MD }\end{array}$ & $\begin{array}{l}\text { Laboratory Krone, Bad } \\
\text { Salzuflen, Germany }\end{array}$ & $\begin{array}{l}\text { Site } \\
\text { investigator }\end{array}$ & $\begin{array}{l}\text { Contributor } \\
\text { to the } \\
\text { GENERATE } \\
\text { registry }\end{array}$ \\
\hline $\begin{array}{l}\text { Andreas Binder, } \\
\text { MD }\end{array}$ & $\begin{array}{l}\text { Division of Neurological } \\
\text { Pain Research and } \\
\text { Therapy, Department of } \\
\text { Neurology, University } \\
\text { Hospital of Schleswig- } \\
\text { Holstein, Kiel, Germany }\end{array}$ & $\begin{array}{l}\text { Site } \\
\text { investigator }\end{array}$ & $\begin{array}{l}\text { Contributor } \\
\text { to the } \\
\text { GENERATE } \\
\text { registry }\end{array}$ \\
\hline $\begin{array}{l}\text { Stefan Bittner, } \\
\text { MD }\end{array}$ & $\begin{array}{l}\text { Department of Neurology, } \\
\text { University of Mainz, Mainz, } \\
\text { Germany }\end{array}$ & $\begin{array}{l}\text { Site } \\
\text { investigator }\end{array}$ & $\begin{array}{l}\text { Contributor } \\
\text { to the } \\
\text { GENERATE } \\
\text { registry }\end{array}$ \\
\hline $\begin{array}{l}\text { Daniel Bittner, } \\
\text { MD }\end{array}$ & $\begin{array}{l}\text { Department of Neurology, } \\
\text { Südklinikum Nordhausen, } \\
\text { Nordhausen, Germany }\end{array}$ & $\begin{array}{l}\text { Site } \\
\text { investigator }\end{array}$ & $\begin{array}{l}\text { Contributor } \\
\text { to the } \\
\text { GENERATE } \\
\text { registry }\end{array}$ \\
\hline Franz Blaes, MD & $\begin{array}{l}\text { Department of Neurology, } \\
\text { KKH Gummersbach, } \\
\text { Gummersbach, Germany }\end{array}$ & $\begin{array}{l}\text { Site } \\
\text { investigator }\end{array}$ & $\begin{array}{l}\text { Contributor } \\
\text { to the } \\
\text { GENERATE } \\
\text { registry }\end{array}$ \\
\hline $\begin{array}{l}\text { Astrid Blaschek, } \\
\text { MD }\end{array}$ & $\begin{array}{l}\text { Department of Pediatric } \\
\text { Neurology and } \\
\text { Developmental Medicine } \\
\text { and LMU Center for } \\
\text { Children with Medical } \\
\text { Complexity, Dr von Hauner } \\
\text { Children's Hospital, LMU } \\
\text { Hospital, Ludwig- } \\
\text { Maximilians-Universität, } \\
\text { Germany }\end{array}$ & $\begin{array}{l}\text { Site } \\
\text { investigator }\end{array}$ & $\begin{array}{l}\text { Contributor } \\
\text { to the } \\
\text { GENERATE } \\
\text { registry }\end{array}$ \\
\hline $\begin{array}{l}\text { Justina } \\
\text { Dargvainiene, } \\
\text { MD }\end{array}$ & $\begin{array}{l}\text { Institute of Clinical } \\
\text { Chemistry, University } \\
\text { Hospital Schleswig- } \\
\text { Holstein, Kiel, Schleswig- } \\
\text { Holstein, Germany }\end{array}$ & $\begin{array}{l}\text { Site } \\
\text { investigator }\end{array}$ & $\begin{array}{l}\text { Contributor } \\
\text { to the } \\
\text { GENERATE } \\
\text { registry }\end{array}$ \\
\hline Andre Dik, MD & $\begin{array}{l}\text { Department of } \\
\text { Neurology with } \\
\text { Institute of } \\
\text { Translational } \\
\text { Neurology, } \\
\text { University of Münster, } \\
\text { Münster, Germany }\end{array}$ & $\begin{array}{l}\text { Site } \\
\text { investigator }\end{array}$ & $\begin{array}{l}\text { Contributor } \\
\text { to the } \\
\text { GENERATE } \\
\text { registry }\end{array}$ \\
\hline
\end{tabular}


Appendix 2 (continued)

\begin{tabular}{|c|c|c|c|}
\hline Name & Location & Role & Contribution \\
\hline $\begin{array}{l}\text { Mona } \\
\text { Dreesmann, } \\
\text { MD }\end{array}$ & $\begin{array}{l}\text { Department of Pediatrics, } \\
\text { Ernst von Bergmann } \\
\text { Klinikum, Potsdam, } \\
\text { Germany }\end{array}$ & $\begin{array}{l}\text { Site } \\
\text { investigator }\end{array}$ & $\begin{array}{l}\text { Contributor } \\
\text { to the } \\
\text { GENERATE } \\
\text { registry }\end{array}$ \\
\hline $\begin{array}{l}\text { Friedrich } \\
\text { Ebinger, MD }\end{array}$ & $\begin{array}{l}\text { Pediatric Clinic, St. Vincenz } \\
\text { Hospital, Paderborn, } \\
\text { Germany }\end{array}$ & $\begin{array}{l}\text { Site } \\
\text { investigator }\end{array}$ & $\begin{array}{l}\text { Contributor } \\
\text { to the } \\
\text { GENERATE } \\
\text { registry }\end{array}$ \\
\hline $\begin{array}{l}\text { Lena Edelhoff, } \\
\text { MD }\end{array}$ & $\begin{array}{l}\text { Department of Neurology, } \\
\text { Katholisches } \\
\text { Marienkrankenhaus } \\
\text { gGmbH, Hamburg, } \\
\text { Germany }\end{array}$ & $\begin{array}{l}\text { Site } \\
\text { investigator }\end{array}$ & $\begin{array}{l}\text { Contributor } \\
\text { to the } \\
\text { GENERATE } \\
\text { registry }\end{array}$ \\
\hline $\begin{array}{l}\text { Sven Ehrlich, } \\
\text { MD }\end{array}$ & $\begin{array}{l}\text { Clinic for Neurology and } \\
\text { Neurological Intensive Care } \\
\text { Medicine, Hubertusburg } \\
\text { Hospital, Wermsdorf, } \\
\text { Germany }\end{array}$ & $\begin{array}{l}\text { Site } \\
\text { investigator }\end{array}$ & $\begin{array}{l}\text { Contributor } \\
\text { to the } \\
\text { GENERATE } \\
\text { registry }\end{array}$ \\
\hline $\begin{array}{l}\text { Katharina } \\
\text { Eisenhut, MD }\end{array}$ & $\begin{array}{l}\text { Institute of Clinical } \\
\text { Neuroimmunology, } \\
\text { University Hospital and } \\
\text { Biomedical Center, Ludwig- } \\
\text { Maximilians-University, } \\
\text { Munich, Germany }\end{array}$ & $\begin{array}{l}\text { Site } \\
\text { investigator }\end{array}$ & $\begin{array}{l}\text { Contributor } \\
\text { to the } \\
\text { GENERATE } \\
\text { registry }\end{array}$ \\
\hline $\begin{array}{l}\text { Dominique } \\
\text { Endres, MD }\end{array}$ & $\begin{array}{l}\text { Section for Experimental } \\
\text { Neuropsychiatry, } \\
\text { Department of Psychiatry } \\
\text { and Psychotherapy, } \\
\text { Medical Center - University } \\
\text { of Freiburg, Faculty of } \\
\text { Medicine, University of } \\
\text { Freiburg, Germany; } \\
\text { Department of Psychiatry } \\
\text { and Psychotherapy, } \\
\text { Medical Center - University } \\
\text { of Freiburg, Faculty of } \\
\text { Medicine, University of } \\
\text { Freiburg, Germany }\end{array}$ & $\begin{array}{l}\text { Site } \\
\text { investigator }\end{array}$ & $\begin{array}{l}\text { Contributor } \\
\text { to the } \\
\text { GENERATE } \\
\text { registry }\end{array}$ \\
\hline $\begin{array}{l}\text { Marina } \\
\text { Entscheva, MD }\end{array}$ & $\begin{array}{l}\text { Department of Neurology, } \\
\text { ASKLEPIOS Fachklinikum } \\
\text { Lübben, Lübben, Germany }\end{array}$ & $\begin{array}{l}\text { Site } \\
\text { investigator }\end{array}$ & $\begin{array}{l}\text { Contributor } \\
\text { to the } \\
\text { GENERATE } \\
\text { registry }\end{array}$ \\
\hline $\begin{array}{l}\text { Jürgen Hartmut } \\
\text { Faiss, MD }\end{array}$ & $\begin{array}{l}\text { Department of Neurology, } \\
\text { Asklepios Fachklinikum } \\
\text { Teupitz, Teupitz, Germany }\end{array}$ & $\begin{array}{l}\text { Site } \\
\text { investigator }\end{array}$ & $\begin{array}{l}\text { Contributor } \\
\text { to the } \\
\text { GENERATE } \\
\text { registry }\end{array}$ \\
\hline $\begin{array}{l}\text { Walid Fazeli, } \\
\text { MD }\end{array}$ & $\begin{array}{l}\text { Pediatric Neurology, } \\
\text { Department of Pediatrics, } \\
\text { Faculty of Medicine and } \\
\text { University Hospital } \\
\text { Cologne, University of } \\
\text { Cologne, Cologne, } \\
\text { Germany }\end{array}$ & $\begin{array}{l}\text { Site } \\
\text { investigator }\end{array}$ & $\begin{array}{l}\text { Contributor } \\
\text { to the } \\
\text { GENERATE } \\
\text { registry }\end{array}$ \\
\hline $\begin{array}{l}\text { Alexander } \\
\text { Finke, MD }\end{array}$ & $\begin{array}{l}\text { Department of Neurology, } \\
\text { Städtisches Klinikum } \\
\text { Lüneburg, Lüneburg, } \\
\text { Germany }\end{array}$ & $\begin{array}{l}\text { Site } \\
\text { investigator }\end{array}$ & $\begin{array}{l}\text { Contributor } \\
\text { to the } \\
\text { GENERATE } \\
\text { registry }\end{array}$ \\
\hline Dirk Fitzner, MD & $\begin{array}{l}\text { Department of Neurology, } \\
\text { University of Göttingen, } \\
\text { Göttingen, Germany }\end{array}$ & $\begin{array}{l}\text { Site } \\
\text { investigator }\end{array}$ & $\begin{array}{l}\text { Contributor } \\
\text { to the } \\
\text { GENERATE } \\
\text { registry }\end{array}$ \\
\hline $\begin{array}{l}\text { Marina Flotats- } \\
\text { Bastardas, MD }\end{array}$ & $\begin{array}{l}\text { Department of Pediatric } \\
\text { Neurology, Saarland } \\
\text { University Hospital, } \\
\text { Homburg, Germany }\end{array}$ & $\begin{array}{l}\text { Site } \\
\text { investigator }\end{array}$ & $\begin{array}{l}\text { Contributor } \\
\text { to the } \\
\text { GENERATE } \\
\text { registry }\end{array}$ \\
\hline
\end{tabular}

Appendix 2 (continued)

\begin{tabular}{|c|c|c|c|}
\hline Name & Location & Role & Contribution \\
\hline $\begin{array}{l}\text { Friedemann } \\
\text { Paul, MD }\end{array}$ & $\begin{array}{l}\text { Department of Neurology, } \\
\text { Charité } \\
\text { Universitätsmedizin Berlin, } \\
\text { Corporate Member of Freie } \\
\text { Universität Berlin, } \\
\text { Humboldt-Universität zu } \\
\text { Berlin, Berlin Institute of } \\
\text { Health, Berlin, Germany }\end{array}$ & $\begin{array}{l}\text { Site } \\
\text { investigator }\end{array}$ & $\begin{array}{l}\text { Contributor } \\
\text { to the } \\
\text { GENERATE } \\
\text { registry }\end{array}$ \\
\hline $\begin{array}{l}\text { Manuel Friese, } \\
\text { MD }\end{array}$ & $\begin{array}{l}\text { Institute of } \\
\text { Neuroimmunology and } \\
\text { Multiple Sclerosis, } \\
\text { University Medical Centre } \\
\text { Hamburg-Eppendorf, } \\
\text { Hamburg, Germany }\end{array}$ & $\begin{array}{l}\text { Site } \\
\text { investigator }\end{array}$ & $\begin{array}{l}\text { Contributor } \\
\text { to the } \\
\text { GENERATE } \\
\text { registry }\end{array}$ \\
\hline $\begin{array}{l}\text { Marco Gallus, } \\
\text { MD }\end{array}$ & $\begin{array}{l}\text { Department of Neurology } \\
\text { with Institute of } \\
\text { Translational Neurology, } \\
\text { University of Münster, } \\
\text { Münster, Germany }\end{array}$ & $\begin{array}{l}\text { Site } \\
\text { investigator }\end{array}$ & $\begin{array}{l}\text { Contributor } \\
\text { to the } \\
\text { GENERATE } \\
\text { registry }\end{array}$ \\
\hline $\begin{array}{l}\text { Marcel } \\
\text { Gebhard, MD }\end{array}$ & $\begin{array}{l}\text { Department of Neurology } \\
\text { Martha-Maria Hospital, } \\
\text { Halle/Saale, Academic } \\
\text { Hospital of University Halle- } \\
\text { Wittenberg, Germany }\end{array}$ & $\begin{array}{l}\text { Site } \\
\text { investigator }\end{array}$ & $\begin{array}{l}\text { Contributor } \\
\text { to the } \\
\text { GENERATE } \\
\text { registry }\end{array}$ \\
\hline $\begin{array}{l}\text { Christian Geis, } \\
\text { MD }\end{array}$ & $\begin{array}{l}\text { Section Translational } \\
\text { Neuroimmunology, } \\
\text { Department of Neurology, } \\
\text { Jena University Hospital, } \\
\text { Jena, Germany }\end{array}$ & $\begin{array}{l}\text { Site } \\
\text { investigator }\end{array}$ & $\begin{array}{l}\text { Contributor } \\
\text { to the } \\
\text { GENERATE } \\
\text { registry }\end{array}$ \\
\hline $\begin{array}{l}\text { Anna Gorsler, } \\
\text { MD }\end{array}$ & $\begin{array}{l}\text { Kliniken Beelitz GmbH, } \\
\text { Neurologische } \\
\text { Rehabilitationsklinik, } \\
\text { Beelitz-Heilstätten, } \\
\text { Germany }\end{array}$ & $\begin{array}{l}\text { Site } \\
\text { investigator }\end{array}$ & $\begin{array}{l}\text { Contributor } \\
\text { to the } \\
\text { GENERATE } \\
\text { registry }\end{array}$ \\
\hline Armin Grau, MD & $\begin{array}{l}\text { Department of Neurology, } \\
\text { Klinikum der Stadt } \\
\text { Ludwigshafen am Rhein, } \\
\text { Germany }\end{array}$ & $\begin{array}{l}\text { Site } \\
\text { investigator }\end{array}$ & $\begin{array}{l}\text { Contributor } \\
\text { to the } \\
\text { GENERATE } \\
\text { registry }\end{array}$ \\
\hline $\begin{array}{l}\text { Oliver Grauer, } \\
\text { MD }\end{array}$ & $\begin{array}{l}\text { Neuro-Oncology } \\
\text { Department, University } \\
\text { Hospital Muenster, } \\
\text { Muenster, Germany }\end{array}$ & $\begin{array}{l}\text { Site } \\
\text { investigator }\end{array}$ & $\begin{array}{l}\text { Contributor } \\
\text { to the } \\
\text { GENERATE } \\
\text { registry }\end{array}$ \\
\hline $\begin{array}{l}\text { Catharina Groß, } \\
\text { MD }\end{array}$ & $\begin{array}{l}\text { Department of Neurology } \\
\text { with Institute of } \\
\text { Translational Neurology, } \\
\text { University of Münster, } \\
\text { Münster, Germany }\end{array}$ & $\begin{array}{l}\text { Site } \\
\text { investigator }\end{array}$ & $\begin{array}{l}\text { Contributor } \\
\text { to the } \\
\text { GENERATE } \\
\text { registry }\end{array}$ \\
\hline Halime Gül & $\begin{array}{l}\text { Department of Neurology, } \\
\text { University Hospital Ulm, } \\
\text { Ulm, Germany }\end{array}$ & $\begin{array}{l}\text { Site } \\
\text { investigator }\end{array}$ & $\begin{array}{l}\text { Contributor } \\
\text { to the } \\
\text { GENERATE } \\
\text { registry }\end{array}$ \\
\hline $\begin{array}{l}\text { Robert } \\
\text { Handreka, MD }\end{array}$ & $\begin{array}{l}\text { Department of Neurology, } \\
\text { University of Mainz, Mainz, } \\
\text { Germany }\end{array}$ & $\begin{array}{l}\text { Site } \\
\text { investigator }\end{array}$ & $\begin{array}{l}\text { Contributor } \\
\text { to the } \\
\text { GENERATE } \\
\text { registry }\end{array}$ \\
\hline $\begin{array}{l}\text { Niels Hansen, } \\
\text { MD }\end{array}$ & $\begin{array}{l}\text { Department of Psychiatry } \\
\text { and Psychotherapy, } \\
\text { Göttingen, Germany }\end{array}$ & $\begin{array}{l}\text { Site } \\
\text { investigator }\end{array}$ & $\begin{array}{l}\text { Contributor } \\
\text { to the } \\
\text { GENERATE } \\
\text { registry }\end{array}$ \\
\hline $\begin{array}{l}\text { Martin Häusler, } \\
\text { MD }\end{array}$ & $\begin{array}{l}\text { Division of Neuropediatrics } \\
\text { and Social Pediatrics, } \\
\text { Department of Pediatrics, } \\
\text { University Hospital RWTH } \\
\text { Aachen, Aachen, Germany }\end{array}$ & $\begin{array}{l}\text { Site } \\
\text { investigator }\end{array}$ & $\begin{array}{l}\text { Contributor } \\
\text { to the } \\
\text { GENERATE } \\
\text { registry }\end{array}$ \\
\hline
\end{tabular}

Continued 
Appendix 2 (continued)

\begin{tabular}{|c|c|c|c|}
\hline Name & Location & Role & Contribution \\
\hline $\begin{array}{l}\text { Joachim Havla, } \\
\text { MD }\end{array}$ & $\begin{array}{l}\text { Institute of Clinical } \\
\text { Neuroimmunology, } \\
\text { University Hospital and } \\
\text { Biomedical Center, Ludwig- } \\
\text { Maximilians-University, } \\
\text { Munich, Germany }\end{array}$ & $\begin{array}{l}\text { Site } \\
\text { investigator }\end{array}$ & $\begin{array}{l}\text { Contributor } \\
\text { to the } \\
\text { GENERATE } \\
\text { registry }\end{array}$ \\
\hline $\begin{array}{l}\text { Chung Ha-Yeun, } \\
\text { MD }\end{array}$ & $\begin{array}{l}\text { Section of Translational } \\
\text { Neuroimmunology, Hans } \\
\text { Berger Department of } \\
\text { Neurology, Jena University } \\
\text { Hospital, Jena, Germany }\end{array}$ & $\begin{array}{l}\text { Site } \\
\text { investigator }\end{array}$ & $\begin{array}{l}\text { Contributor } \\
\text { to the } \\
\text { GENERATE } \\
\text { registry }\end{array}$ \\
\hline $\begin{array}{l}\text { Wolfgang } \\
\text { Heide, MD }\end{array}$ & $\begin{array}{l}\text { Department of Neurology, } \\
\text { General Hospital Celle, } \\
\text { Celle, Germany }\end{array}$ & $\begin{array}{l}\text { Site } \\
\text { investigator }\end{array}$ & $\begin{array}{l}\text { Contributor } \\
\text { to the } \\
\text { GENERATE } \\
\text { registry }\end{array}$ \\
\hline $\begin{array}{l}\text { Valentin Held, } \\
\text { MD }\end{array}$ & $\begin{array}{l}\text { Department of Neurology, } \\
\text { Universitätsmedizin } \\
\text { Mannheim, Heidelberg } \\
\text { University, Mannheim, } \\
\text { Germany }\end{array}$ & $\begin{array}{l}\text { Site } \\
\text { investigator }\end{array}$ & $\begin{array}{l}\text { Contributor } \\
\text { to the } \\
\text { GENERATE } \\
\text { registry }\end{array}$ \\
\hline $\begin{array}{l}\text { Kerstin Hellwig, } \\
\text { MD }\end{array}$ & $\begin{array}{l}\text { Department of Neurology, } \\
\text { St. Josef Hospital, Ruhr } \\
\text { University Bochum, } \\
\text { Bochum, Germany }\end{array}$ & $\begin{array}{l}\text { Site } \\
\text { investigator }\end{array}$ & $\begin{array}{l}\text { Contributor } \\
\text { to the } \\
\text { GENERATE } \\
\text { registry }\end{array}$ \\
\hline $\begin{array}{l}\text { Philip } \\
\text { Hillebrand, MD }\end{array}$ & $\begin{array}{l}\text { Division of Pediatric } \\
\text { Nephrology, Department } \\
\text { of Pediatrics, University } \\
\text { Children's Hospital Bonn, } \\
\text { Bonn, Germany }\end{array}$ & $\begin{array}{l}\text { Site } \\
\text { investigator }\end{array}$ & $\begin{array}{l}\text { Contributor } \\
\text { to the } \\
\text { GENERATE } \\
\text { registry }\end{array}$ \\
\hline $\begin{array}{l}\text { Frank } \\
\text { Hoffmann, MD }\end{array}$ & $\begin{array}{l}\text { Department of Neurology, } \\
\text { Krankenhaus Martha- } \\
\text { Maria Halle-Doelau, } \\
\text { Germany }\end{array}$ & $\begin{array}{l}\text { Site } \\
\text { investigator }\end{array}$ & $\begin{array}{l}\text { Contributor } \\
\text { to the } \\
\text { GENERATE } \\
\text { registry }\end{array}$ \\
\hline $\begin{array}{l}\text { Ulrich Hofstadt- } \\
\text { van Oy, MD }\end{array}$ & $\begin{array}{l}\text { Klinik für Neurologie, } \\
\text { Knappschaftskrankenhaus } \\
\text { Dortmund, Klinikum } \\
\text { Westfalen, } \\
\text { Dortmund, Germany }\end{array}$ & $\begin{array}{l}\text { Site } \\
\text { investigator }\end{array}$ & $\begin{array}{l}\text { Contributor } \\
\text { to the } \\
\text { GENERATE } \\
\text { registry }\end{array}$ \\
\hline $\begin{array}{l}\text { Fatme Seval } \\
\text { Ismail, MD }\end{array}$ & $\begin{array}{l}\text { Department of Neurology, } \\
\text { University Hospital } \\
\text { Knappschaftskrankenhaus } \\
\text { Bochum, Ruhr University } \\
\text { Bochum, Bochum, } \\
\text { Germany }\end{array}$ & $\begin{array}{l}\text { Site } \\
\text { investigator }\end{array}$ & $\begin{array}{l}\text { Contributor } \\
\text { to the } \\
\text { GENERATE } \\
\text { registry }\end{array}$ \\
\hline Martina Jansen & $\begin{array}{l}\text { Neuroimmunology section, } \\
\text { Institute of Clinical } \\
\text { Chemistry, University } \\
\text { Hospital Schleswig- } \\
\text { Holstein Kiel/Lübeck, } \\
\text { Germany }\end{array}$ & $\begin{array}{l}\text { Site } \\
\text { investigator }\end{array}$ & $\begin{array}{l}\text { Contributor } \\
\text { to the } \\
\text { GENERATE } \\
\text { registry }\end{array}$ \\
\hline $\begin{array}{l}\text { Max Kaufmann, } \\
\text { MD }\end{array}$ & $\begin{array}{l}\text { Institute of } \\
\text { Neuroimmunology and } \\
\text { Multiple Sclerosis, } \\
\text { University Medical Center } \\
\text { Hamburg-Eppendorf, } \\
\text { Hamburg, Germany }\end{array}$ & $\begin{array}{l}\text { Site } \\
\text { investigator }\end{array}$ & $\begin{array}{l}\text { Contributor } \\
\text { to the } \\
\text { GENERATE } \\
\text { registry }\end{array}$ \\
\hline $\begin{array}{l}\text { Christoph } \\
\text { Kellinghaus, } \\
\text { MD }\end{array}$ & $\begin{array}{l}\text { Department of Neurology, } \\
\text { Klinikum Osnabrück, } \\
\text { Osnabrück, Germany }\end{array}$ & $\begin{array}{l}\text { Site } \\
\text { investigator }\end{array}$ & $\begin{array}{l}\text { Contributor } \\
\text { to the } \\
\text { GENERATE } \\
\text { registry }\end{array}$ \\
\hline $\begin{array}{l}\text { Susanne Knake, } \\
\text { MD }\end{array}$ & $\begin{array}{l}\text { Epilepsy Center Hessen, } \\
\text { Department of Neurology, } \\
\text { Philipps University Marburg, } \\
\text { Marburg, Germany }\end{array}$ & $\begin{array}{l}\text { Site } \\
\text { investigator }\end{array}$ & $\begin{array}{l}\text { Contributor } \\
\text { to the } \\
\text { GENERATE } \\
\text { registry }\end{array}$ \\
\hline
\end{tabular}

Appendix 2 (continued)

\begin{tabular}{|c|c|c|c|}
\hline Name & Location & Role & Contribution \\
\hline $\begin{array}{l}\text { Peter } \\
\text { Körtvelyessy, } \\
\text { MD }\end{array}$ & $\begin{array}{l}\text { German Center for } \\
\text { Neurodegenerative } \\
\text { Diseases (DZNE) } \\
\text { Magdeburg, Magdeburg, } \\
\text { Germany; Institute for } \\
\text { Cognitive Neurology } \\
\text { and Dementia } \\
\text { Research, Magdeburg, } \\
\text { Germany; Charité } \\
\text { Universitätsmedizin } \\
\text { Berlin, Department of } \\
\text { Neurology and } \\
\text { Experimental } \\
\text { Neurology, Berlin, } \\
\text { Germany }\end{array}$ & $\begin{array}{l}\text { Site } \\
\text { investigator }\end{array}$ & $\begin{array}{l}\text { Contributor } \\
\text { to the } \\
\text { GENERATE } \\
\text { registry }\end{array}$ \\
\hline
\end{tabular}

\begin{tabular}{llll}
\hline Stjepana Kovac, & $\begin{array}{l}\text { Department of Neurology } \\
\text { with Institute of }\end{array}$ & $\begin{array}{l}\text { Site } \\
\text { investigator }\end{array}$ & $\begin{array}{l}\text { Contributor } \\
\text { to the }\end{array}$ \\
& Translational Neurology, & & GENERATE \\
& University Hospital & registry \\
& Münster, Münster, & \\
& Germany & \\
\end{tabular}

\begin{tabular}{llll}
\hline $\begin{array}{l}\text { Markus } \\
\text { Krämer, MD }\end{array}$ & $\begin{array}{l}\text { Department of Neurology, } \\
\text { Alfried Krupp Hospital, } \\
\text { Essen, Germany }\end{array}$ & $\begin{array}{l}\text { Site } \\
\text { investigator }\end{array}$ & $\begin{array}{l}\text { Contributor } \\
\text { to the } \\
\text { GENERATE } \\
\text { registry }\end{array}$ \\
\hline $\begin{array}{l}\text { Christos } \\
\text { Krogias, MD }\end{array}$ & $\begin{array}{l}\text { Department of } \\
\text { Neurology, St. Josef } \\
\text { Hospital Bochum, Ruhr } \\
\text { University Bochum, } \\
\text { Germany, Medical }\end{array}$ & $\begin{array}{l}\text { Site } \\
\text { investigator }\end{array}$ & $\begin{array}{l}\text { Contributor } \\
\text { to the } \\
\text { GENERATE } \\
\text { registry }\end{array}$ \\
& & &
\end{tabular}

Germany; Medical

Faculty, Ruhr

University

Bochum, Germany

\begin{tabular}{llll}
\hline Christoph & Clinic of Neurology with & Site & Contributor \\
Lehrich, MD & Institute of Translational & investigator & to the \\
& Neurology, University of & & GENERATE \\
& Münster, Münster, & & registry \\
& Germany &
\end{tabular}

\begin{tabular}{|c|c|c|c|}
\hline $\begin{array}{l}\text { Andreas Linsa, } \\
\text { MD }\end{array}$ & $\begin{array}{l}\text { Klinik für Neurologie, Carl- } \\
\text { Thiem Klinikum Cottbus } \\
\text { gGmbH, Cottbus, Germany }\end{array}$ & $\begin{array}{l}\text { Site } \\
\text { investigator }\end{array}$ & $\begin{array}{l}\text { Contributor } \\
\text { to the } \\
\text { GENERATE } \\
\text { registry }\end{array}$ \\
\hline $\begin{array}{l}\text { Jan Lünemann, } \\
\text { MD }\end{array}$ & $\begin{array}{l}\text { Department of Neurology } \\
\text { with Institute of } \\
\text { Translational Neurology, } \\
\text { University Hospital } \\
\text { Münster, Münster, } \\
\text { Germany }\end{array}$ & $\begin{array}{l}\text { Site } \\
\text { investigator }\end{array}$ & $\begin{array}{l}\text { Contributor } \\
\text { to the } \\
\text { GENERATE } \\
\text { registry }\end{array}$ \\
\hline $\begin{array}{l}\text { Michael Malter, } \\
\text { MD }\end{array}$ & $\begin{array}{l}\text { University of Cologne, } \\
\text { Faculty of Medicine, } \\
\text { University Hospital } \\
\text { Cologne, Department of } \\
\text { Neurology, Cologne, } \\
\text { Germany }\end{array}$ & $\begin{array}{l}\text { Site } \\
\text { investigator }\end{array}$ & $\begin{array}{l}\text { Contributor } \\
\text { to the } \\
\text { GENERATE } \\
\text { registry }\end{array}$ \\
\hline
\end{tabular}

Kristin Stefanie Department of Neurology Site Contributor

Melzer, MD with Institute of investigator to the Translational Neurology, GENERATE University Hospital registry Münster, Münster, Germany

\begin{tabular}{llll}
\hline Til Menge, MD & $\begin{array}{l}\text { Centre for Neurology and } \\
\text { Neuropsychiatry, LVR- } \\
\text { Klinikum Düsseldorf, } \\
\text { Medical Faculty, Heinrich }\end{array}$ & $\begin{array}{l}\text { Site } \\
\text { investigator }\end{array}$ & $\begin{array}{l}\text { Contributor } \\
\text { to the } \\
\text { GeNERATE }\end{array}$ \\
& Heine University & registry \\
& Düsseldorf, Düsseldorf, & \\
& Germany &
\end{tabular}


Appendix 2 (continued)

\begin{tabular}{|c|c|c|c|}
\hline Name & Location & Role & Contribution \\
\hline $\begin{array}{l}\text { Sven Meuth, } \\
\text { MD }\end{array}$ & $\begin{array}{l}\text { Department of Neurology } \\
\text { with Institute of } \\
\text { Translational Neurology, } \\
\text { University Hospital } \\
\text { Münster, Münster, } \\
\text { Germany/Department } \\
\text { of Neurology, Heinrich } \\
\text { Heine University } \\
\text { Düsseldorf, Düsseldorf, } \\
\text { Germany }\end{array}$ & $\begin{array}{l}\text { Site } \\
\text { investigator }\end{array}$ & $\begin{array}{l}\text { Contributor } \\
\text { to the } \\
\text { GENERATE } \\
\text { registry }\end{array}$ \\
\hline $\begin{array}{l}\text { Gerd Meyer zu } \\
\text { Hörste, MD }\end{array}$ & $\begin{array}{l}\text { Department of Neurology } \\
\text { with Institute of Translational } \\
\text { Neurology, University and } \\
\text { University Hospital Münster, } \\
\text { Münster, Germany }\end{array}$ & $\begin{array}{l}\text { Site } \\
\text { investigator }\end{array}$ & $\begin{array}{l}\text { Contributor } \\
\text { to the } \\
\text { GENERATE } \\
\text { registry }\end{array}$ \\
\hline $\begin{array}{l}\text { Constanze } \\
\text { Mönig, MD }\end{array}$ & $\begin{array}{l}\text { Department of Neurology, } \\
\text { University of Münster, } \\
\text { Münster, Germany }\end{array}$ & $\begin{array}{l}\text { Site } \\
\text { investigator }\end{array}$ & $\begin{array}{l}\text { Contributor } \\
\text { to the } \\
\text { GENERATE } \\
\text { registry }\end{array}$ \\
\hline $\begin{array}{l}\text { Marie-Luise } \\
\text { Mono, MD }\end{array}$ & $\begin{array}{l}\text { Stadtspital Waid und } \\
\text { Triemli, Zurich, Switzerland }\end{array}$ & $\begin{array}{l}\text { Site } \\
\text { investigator }\end{array}$ & $\begin{array}{l}\text { Contributor } \\
\text { to the } \\
\text { GENERATE } \\
\text { registry }\end{array}$ \\
\hline $\begin{array}{l}\text { Michael Nagel, } \\
\text { MD }\end{array}$ & $\begin{array}{l}\text { Department of Neurology, } \\
\text { Klinikum Osnabrück, } \\
\text { Osnabrück, Germany }\end{array}$ & $\begin{array}{l}\text { Site } \\
\text { investigator }\end{array}$ & $\begin{array}{l}\text { Contributor } \\
\text { to the } \\
\text { GENERATE } \\
\text { registry }\end{array}$ \\
\hline $\begin{array}{l}\text { Tobias } \\
\text { Neumann- } \\
\text { Haefelin, MD }\end{array}$ & $\begin{array}{l}\text { Department of Neurology, } \\
\text { Klinikum Fulda, Fulda, } \\
\text { Germany }\end{array}$ & $\begin{array}{l}\text { Site } \\
\text { investigator }\end{array}$ & $\begin{array}{l}\text { Contributor } \\
\text { to the } \\
\text { GENERATE } \\
\text { registry }\end{array}$ \\
\hline $\begin{array}{l}\text { Jost Obrocki, } \\
\text { MD }\end{array}$ & $\begin{array}{l}\text { Clinic for Psychiatry and } \\
\text { Psychotherapy, Sana Regio } \\
\text { Kliniken-Klinikum } \\
\text { Elmshorn, Germany }\end{array}$ & $\begin{array}{l}\text { Site } \\
\text { investigator }\end{array}$ & $\begin{array}{l}\text { Contributor } \\
\text { to the } \\
\text { GENERATE } \\
\text { registry }\end{array}$ \\
\hline $\begin{array}{l}\text { Thomas } \\
\text { Pfefferkorn, } \\
\text { MD }\end{array}$ & $\begin{array}{l}\text { Department of Neurology, } \\
\text { Klinikum Ingolstadt, } \\
\text { Ingolstadt, Germany }\end{array}$ & $\begin{array}{l}\text { Site } \\
\text { investigator }\end{array}$ & $\begin{array}{l}\text { Contributor } \\
\text { to the } \\
\text { GENERATE } \\
\text { registry }\end{array}$ \\
\hline $\begin{array}{l}\text { Alexandra } \\
\text { Philipsen, MD }\end{array}$ & $\begin{array}{l}\text { Department of Psychiatry } \\
\text { and Psychotherapy, } \\
\text { University of Bonn, } \\
\text { Germany }\end{array}$ & $\begin{array}{l}\text { Site } \\
\text { investigator }\end{array}$ & $\begin{array}{l}\text { Contributor } \\
\text { to the } \\
\text { GENERATE } \\
\text { registry }\end{array}$ \\
\hline $\begin{array}{l}\text { Johannes } \\
\text { Piepgras, MD }\end{array}$ & $\begin{array}{l}\text { Department of } \\
\text { Neurology, Focus } \\
\text { Program Translational } \\
\text { Neuroscience and } \\
\text { Immunotherapy, Rhine- } \\
\text { Main Neuroscience } \\
\text { Network, University } \\
\text { Medical Center of the } \\
\text { Johannes Gutenberg } \\
\text { University Mainz, } \\
\text { Mainz, Germany }\end{array}$ & $\begin{array}{l}\text { Site } \\
\text { investigator }\end{array}$ & $\begin{array}{l}\text { Contributor } \\
\text { to the } \\
\text { GENERATE } \\
\text { registry }\end{array}$ \\
\hline $\begin{array}{l}\text { Felix von } \\
\text { Podewils, MD }\end{array}$ & $\begin{array}{l}\text { Department of } \\
\text { Neurology, Epilepsy } \\
\text { Center, University } \\
\text { Medicine Greifswald, } \\
\text { Greifswald, Germany }\end{array}$ & $\begin{array}{l}\text { Site } \\
\text { investigator }\end{array}$ & $\begin{array}{l}\text { Contributor } \\
\text { to the } \\
\text { GENERATE } \\
\text { registry }\end{array}$ \\
\hline Josef Priller, MD & $\begin{array}{l}\text { Department of } \\
\text { Neuropsychiatry, } \\
\text { Charité, } \\
\text { Universitätsmedizin, } \\
\text { Berlin, Germany }\end{array}$ & $\begin{array}{l}\text { Site } \\
\text { investigator }\end{array}$ & $\begin{array}{l}\text { Contributor } \\
\text { to the } \\
\text { GENERATE } \\
\text { registry }\end{array}$ \\
\hline
\end{tabular}

Appendix 2 (continued)

\begin{tabular}{llll}
\hline Name & Location & Role & Contribution \\
\hline Anne-Katrin & Neurologic Clinic and & Site & Contributor \\
Pröbstel, MD & $\begin{array}{l}\text { Policlinic, Departments of } \\
\text { Medicine and Biomedicine, }\end{array}$ & investigator & to the \\
& University Hospital of & GENERATE \\
& Basel, University of Basel, & & registry \\
& Basel, Switzerland & & \\
& &
\end{tabular}

\begin{tabular}{|c|c|c|c|}
\hline $\begin{array}{l}\text { Johanna Maria } \\
\text { Helena Rau, MD }\end{array}$ & $\begin{array}{l}\text { Department of Neurology } \\
\text { with Institute of } \\
\text { Translational Neurology, } \\
\text { University of Münster, } \\
\text { Münster, Germany }\end{array}$ & $\begin{array}{l}\text { Site } \\
\text { investigator }\end{array}$ & $\begin{array}{l}\text { Contributor } \\
\text { to the } \\
\text { GENERATE } \\
\text { registry }\end{array}$ \\
\hline $\begin{array}{l}\text { Saskia Jania } \\
\text { Räuber, MD }\end{array}$ & $\begin{array}{l}\text { Department of Neurology } \\
\text { with Institute of } \\
\text { Translational Neurology, } \\
\text { University of Münster, } \\
\text { Münster, Germany }\end{array}$ & $\begin{array}{l}\text { Site } \\
\text { investigator }\end{array}$ & $\begin{array}{l}\text { Contributor } \\
\text { to the } \\
\text { GENERATE } \\
\text { registry }\end{array}$ \\
\hline $\begin{array}{l}\text { Gernot } \\
\text { Reimann, MD }\end{array}$ & $\begin{array}{l}\text { Department of Neurology, } \\
\text { Klinikum Dortmund, } \\
\text { Dortmund, Germany }\end{array}$ & $\begin{array}{l}\text { Site } \\
\text { investigator }\end{array}$ & $\begin{array}{l}\text { Contributor } \\
\text { to the } \\
\text { GENERATE } \\
\text { registry }\end{array}$ \\
\hline $\begin{array}{l}\text { Raphael } \\
\text { Reinecke, MD }\end{array}$ & $\begin{array}{l}\text { Epilepsy Center Frankfurt } \\
\text { Rhine-Main and } \\
\text { Department of Neurology, } \\
\text { University Hospital and } \\
\text { Goethe University } \\
\text { Frankfurt, Frankfurt am } \\
\text { Main, Germany }\end{array}$ & $\begin{array}{l}\text { Site } \\
\text { investigator }\end{array}$ & $\begin{array}{l}\text { Contributor } \\
\text { to the } \\
\text { GENERATE } \\
\text { registry }\end{array}$ \\
\hline $\begin{array}{l}\text { Marius } \\
\text { Ringelstein, MD }\end{array}$ & $\begin{array}{l}\text { Department of Neurology, } \\
\text { Medical Faculty, Heinrich } \\
\text { Heine University } \\
\text { Düsseldorf, Düsseldorf, } \\
\text { Germany }\end{array}$ & $\begin{array}{l}\text { Site } \\
\text { investigator }\end{array}$ & $\begin{array}{l}\text { Contributor } \\
\text { to the } \\
\text { GENERATE } \\
\text { registry }\end{array}$ \\
\hline $\begin{array}{l}\text { Hendrik } \\
\text { Rohner, MD }\end{array}$ & $\begin{array}{l}\text { Department of Psychiatry } \\
\text { and Psychotherapy, } \\
\text { University of Bonn, Bonn, } \\
\text { Germany }\end{array}$ & $\begin{array}{l}\text { Site } \\
\text { investigator }\end{array}$ & $\begin{array}{l}\text { Contributor } \\
\text { to the } \\
\text { GENERATE } \\
\text { registry }\end{array}$ \\
\hline $\begin{array}{l}\text { Felix Rosenow, } \\
\text { MD }\end{array}$ & $\begin{array}{l}\text { Epilepsy Center Frankfurt } \\
\text { Rhine-Main and } \\
\text { Department of Neurology, } \\
\text { Goethe University } \\
\text { Frankfurt, Frankfurt am } \\
\text { Main, Germany }\end{array}$ & $\begin{array}{l}\text { Site } \\
\text { investigator }\end{array}$ & $\begin{array}{l}\text { Contributor } \\
\text { to the } \\
\text { GENERATE } \\
\text { registry }\end{array}$ \\
\hline $\begin{array}{l}\text { Kevin Rostásy, } \\
\text { MD }\end{array}$ & $\begin{array}{l}\text { Pediatric Neurology, } \\
\text { University of Witten/ } \\
\text { Herdecke, Children's Hospital } \\
\text { Datteln, Datteln, Germany }\end{array}$ & $\begin{array}{l}\text { Site } \\
\text { investigator }\end{array}$ & $\begin{array}{l}\text { Contributor } \\
\text { to the } \\
\text { GENERATE } \\
\text { registry }\end{array}$ \\
\hline $\begin{array}{l}\text { Stephan Rüegg, } \\
\text { MD }\end{array}$ & $\begin{array}{l}\text { Department of Neurology, } \\
\text { University Hospital Basel } \\
\text { and University of Basel, } \\
\text { Basel, Switzerland }\end{array}$ & $\begin{array}{l}\text { Site } \\
\text { investigator }\end{array}$ & $\begin{array}{l}\text { Contributor } \\
\text { to the } \\
\text { GENERATE } \\
\text { registry }\end{array}$ \\
\hline $\begin{array}{l}\text { Jens } \\
\text { Schaumberg, } \\
\text { MD }\end{array}$ & $\begin{array}{l}\text { Department of Neurology, } \\
\text { Community Hospital Helios } \\
\text { Klinikum Uelzen, Uelzen, } \\
\text { Germany }\end{array}$ & $\begin{array}{l}\text { Site } \\
\text { investigator }\end{array}$ & $\begin{array}{l}\text { Contributor } \\
\text { to the } \\
\text { GENERATE } \\
\text { registry }\end{array}$ \\
\hline $\begin{array}{l}\text { Jens Schmidt, } \\
\text { MD }\end{array}$ & $\begin{array}{l}\text { Department of Neurology, } \\
\text { Neuromuscular Centre, } \\
\text { Göttingen, Germany }\end{array}$ & $\begin{array}{l}\text { Site } \\
\text { investigator }\end{array}$ & $\begin{array}{l}\text { Contributor } \\
\text { to the } \\
\text { GENERATE } \\
\text { registry }\end{array}$ \\
\hline $\begin{array}{l}\text { Ina-Isabelle } \\
\text { Schmütz }\end{array}$ & $\begin{array}{l}\text { Neuroimmunology section, } \\
\text { Institute of Clinical } \\
\text { Chemistry, University } \\
\text { Hospital Schleswig-Holstein } \\
\text { Kiel/Lübeck, Germany }\end{array}$ & $\begin{array}{l}\text { Site } \\
\text { investigator }\end{array}$ & $\begin{array}{l}\text { Contributor } \\
\text { to the } \\
\text { GENERATE } \\
\text { registry }\end{array}$ \\
\hline
\end{tabular}


Appendix 2 (continued)

\begin{tabular}{|c|c|c|c|}
\hline Name & Location & Role & Contribution \\
\hline $\begin{array}{l}\text { Stephan } \\
\text { Schreiber, MD }\end{array}$ & $\begin{array}{l}\text { Department of Neurology, } \\
\text { Asklepios Fachklinikum, } \\
\text { Brandenburg, Germany }\end{array}$ & $\begin{array}{l}\text { Site } \\
\text { investigator }\end{array}$ & $\begin{array}{l}\text { Contributor } \\
\text { to the } \\
\text { GENERATE } \\
\text { registry }\end{array}$ \\
\hline Gesa Schreyer & $\begin{array}{l}\text { Neuroimmunology section, } \\
\text { Institute of Clinical } \\
\text { Chemistry, University } \\
\text { Hospital Schleswig-Holstein } \\
\text { Kiel/Lübeck, Germany }\end{array}$ & $\begin{array}{l}\text { Site } \\
\text { investigator }\end{array}$ & $\begin{array}{l}\text { Contributor } \\
\text { to the } \\
\text { GENERATE } \\
\text { registry }\end{array}$ \\
\hline Ina Schröder & $\begin{array}{l}\text { Neuroimmunology section, } \\
\text { Institute of Clinical } \\
\text { Chemistry, University } \\
\text { Hospital Schleswig-Holstein } \\
\text { Kiel/Lübeck, Germany }\end{array}$ & $\begin{array}{l}\text { Site } \\
\text { investigator }\end{array}$ & $\begin{array}{l}\text { Contributor } \\
\text { to the } \\
\text { GENERATE } \\
\text { registry }\end{array}$ \\
\hline $\begin{array}{l}\text { Simon } \\
\text { Schuster, MD }\end{array}$ & $\begin{array}{l}\text { Center for Integrative } \\
\text { Psychiatry, University } \\
\text { Hospital Schleswig- } \\
\text { Holstein, Lübeck, } \\
\text { Germany }\end{array}$ & $\begin{array}{l}\text { Site } \\
\text { investigator }\end{array}$ & $\begin{array}{l}\text { Contributor } \\
\text { to the } \\
\text { GENERATE } \\
\text { registry }\end{array}$ \\
\hline $\begin{array}{l}\text { Günter Seidel, } \\
\text { MD }\end{array}$ & $\begin{array}{l}\text { Department of Neurology, } \\
\text { Asklepios Klinik Nord, } \\
\text { Hamburg, Germany }\end{array}$ & $\begin{array}{l}\text { Site } \\
\text { investigator }\end{array}$ & $\begin{array}{l}\text { Contributor } \\
\text { to the } \\
\text { GENERATE } \\
\text { registry }\end{array}$ \\
\hline $\begin{array}{l}\text { Makbule Senel, } \\
\text { MD }\end{array}$ & $\begin{array}{l}\text { Department of Neurology, } \\
\text { University Hospital Ulm, } \\
\text { Ulm, Germany }\end{array}$ & $\begin{array}{l}\text { Site } \\
\text { investigator }\end{array}$ & $\begin{array}{l}\text { Contributor } \\
\text { to the } \\
\text { GENERATE } \\
\text { registry }\end{array}$ \\
\hline $\begin{array}{l}\text { Kai } \\
\text { Siebenbrodt, } \\
\text { MD }\end{array}$ & $\begin{array}{l}\text { Epilepsy Center Frankfurt } \\
\text { Rhine-Main and } \\
\text { Department of Neurology, } \\
\text { University Hospital and } \\
\text { Goethe University } \\
\text { Frankfurt, Frankfurt am } \\
\text { Main, Germany; LOEWE } \\
\text { Center for Personalized } \\
\text { Translational Epilepsy } \\
\text { Research (CePTER), Goethe } \\
\text { University Frankfurt, } \\
\text { Frankfurt am Main, } \\
\text { Germany }\end{array}$ & $\begin{array}{l}\text { Site } \\
\text { investigator }\end{array}$ & $\begin{array}{l}\text { Contributor } \\
\text { to the } \\
\text { GENERATE } \\
\text { registry }\end{array}$ \\
\hline $\begin{array}{l}\text { Oliver Stammel, } \\
\text { MD }\end{array}$ & $\begin{array}{l}\text { Department of Neurology, } \\
\text { ASKLEPIOS Klinik Hamburg } \\
\text { Barmbek, Hamburg, } \\
\text { Germany }\end{array}$ & $\begin{array}{l}\text { Site } \\
\text { investigator }\end{array}$ & $\begin{array}{l}\text { Contributor } \\
\text { to the } \\
\text { GENERATE } \\
\text { registry }\end{array}$ \\
\hline $\begin{array}{l}\text { Martin Stangel, } \\
\text { MD }\end{array}$ & $\begin{array}{l}\text { Department of Neurology, } \\
\text { Hannover Medical School, } \\
\text { Hannover, Germany }\end{array}$ & $\begin{array}{l}\text { Site } \\
\text { investigator }\end{array}$ & $\begin{array}{l}\text { Contributor } \\
\text { to the } \\
\text { GENERATE } \\
\text { registry }\end{array}$ \\
\hline $\begin{array}{l}\text { Henning Stolze, } \\
\text { MD }\end{array}$ & $\begin{array}{l}\text { Department of Neurology, } \\
\text { Diako Flensburg, Germany }\end{array}$ & $\begin{array}{l}\text { Site } \\
\text { investigator }\end{array}$ & $\begin{array}{l}\text { Contributor } \\
\text { to the } \\
\text { GENERATE } \\
\text { registry }\end{array}$ \\
\hline $\begin{array}{l}\text { Muriel Stoppe, } \\
\text { MD }\end{array}$ & $\begin{array}{l}\text { Department of Neurology, } \\
\text { University of Leipzig, } \\
\text { Leipzig, Germany }\end{array}$ & $\begin{array}{l}\text { Site } \\
\text { investigator }\end{array}$ & $\begin{array}{l}\text { Contributor } \\
\text { to the } \\
\text { GENERATE } \\
\text { registry }\end{array}$ \\
\hline $\begin{array}{l}\text { Karin Storm } \\
\text { van's } \\
\text { Gravesande, } \\
\text { MD }\end{array}$ & $\begin{array}{l}\text { Department of } \\
\text { Pediatrics, University } \\
\text { Hospital Klinikum } \\
\text { rechts der Isar, } \\
\text { Technical University } \\
\text { of Munich, School of } \\
\text { Medicine, Munich, } \\
\text { Germany }\end{array}$ & $\begin{array}{l}\text { Site } \\
\text { investigator }\end{array}$ & $\begin{array}{l}\text { Contributor } \\
\text { to the } \\
\text { GENERATE } \\
\text { registry }\end{array}$ \\
\hline
\end{tabular}

Appendix 2 (continued)

\begin{tabular}{|c|c|c|c|}
\hline Name & Location & Role & Contribution \\
\hline $\begin{array}{l}\text { Steffen Sybre, } \\
\text { MD }\end{array}$ & $\begin{array}{l}\text { Clinic for Pediatric and } \\
\text { Adolescent Medicine, } \\
\text { Heidelberg University, } \\
\text { Heidelberg, Germany }\end{array}$ & $\begin{array}{l}\text { Site } \\
\text { investigator }\end{array}$ & $\begin{array}{l}\text { Contributor } \\
\text { to the } \\
\text { GENERATE } \\
\text { registry }\end{array}$ \\
\hline $\begin{array}{l}\text { Simone Tauber, } \\
\text { MD }\end{array}$ & $\begin{array}{l}\text { Department of Neurology, } \\
\text { RWTH University Hospital, } \\
\text { Aachen, Germany }\end{array}$ & $\begin{array}{l}\text { Site } \\
\text { investigator }\end{array}$ & $\begin{array}{l}\text { Contributor } \\
\text { to the } \\
\text { GENERATE } \\
\text { registry }\end{array}$ \\
\hline $\begin{array}{l}\text { Florian Then } \\
\text { Bergh, MD }\end{array}$ & $\begin{array}{l}\text { Department of Neurology, } \\
\text { Universität Leipzig, } \\
\text { Germany }\end{array}$ & $\begin{array}{l}\text { Site } \\
\text { investigator }\end{array}$ & $\begin{array}{l}\text { Contributor } \\
\text { to the } \\
\text { GENERATE } \\
\text { registry }\end{array}$ \\
\hline $\begin{array}{l}\text { Corinna Trebst, } \\
\text { MD }\end{array}$ & $\begin{array}{l}\text { Department of Neurology, } \\
\text { Hannover Medical School, } \\
\text { Hannover, Germany }\end{array}$ & $\begin{array}{l}\text { Site } \\
\text { investigator }\end{array}$ & $\begin{array}{l}\text { Contributor } \\
\text { to the } \\
\text { GENERATE } \\
\text { registry }\end{array}$ \\
\hline $\begin{array}{l}\text { George } \\
\text { Trendelenburg, } \\
\text { MD }\end{array}$ & $\begin{array}{l}\text { Department of Neurology, } \\
\text { University of Göttingen } \\
\text { Medical Center, Göttingen, } \\
\text { Germany }\end{array}$ & $\begin{array}{l}\text { Site } \\
\text { investigator }\end{array}$ & $\begin{array}{l}\text { Contributor } \\
\text { to the } \\
\text { GENERATE } \\
\text { registry }\end{array}$ \\
\hline $\begin{array}{l}\text { Regina } \\
\text { Trollmann, MD }\end{array}$ & $\begin{array}{l}\text { Department of Pediatrics } \\
\text { and Pediatric Neurology, } \\
\text { Friedrich-Alexander- } \\
\text { Universität Erlangen- } \\
\text { Nürnberg, Erlangen, } \\
\text { Germany }\end{array}$ & $\begin{array}{l}\text { Site } \\
\text { investigator }\end{array}$ & $\begin{array}{l}\text { Contributor } \\
\text { to the } \\
\text { GENERATE } \\
\text { registry }\end{array}$ \\
\hline $\begin{array}{l}\text { Hayrettin } \\
\text { Tumani, MD }\end{array}$ & $\begin{array}{l}\text { Department of Neurology, } \\
\text { University Hospital Ulm, } \\
\text { Ulm, Germany }\end{array}$ & $\begin{array}{l}\text { Site } \\
\text { investigator }\end{array}$ & $\begin{array}{l}\text { Contributor } \\
\text { to the } \\
\text { GENERATE } \\
\text { registry }\end{array}$ \\
\hline Methab Türedi & $\begin{array}{l}\text { Department of Neurology, } \\
\text { University Hospital Ulm, } \\
\text { Ulm, Germany }\end{array}$ & $\begin{array}{l}\text { Site } \\
\text { investigator }\end{array}$ & $\begin{array}{l}\text { Contributor } \\
\text { to the } \\
\text { GENERATE } \\
\text { registry }\end{array}$ \\
\hline $\begin{array}{l}\text { Matthias von } \\
\text { Mering, MD }\end{array}$ & $\begin{array}{l}\text { Department of Neurology, } \\
\text { University of Göttingen, } \\
\text { Göttingen, Germany }\end{array}$ & $\begin{array}{l}\text { Site } \\
\text { investigator }\end{array}$ & $\begin{array}{l}\text { Contributor } \\
\text { to the } \\
\text { GENERATE } \\
\text { registry }\end{array}$ \\
\hline $\begin{array}{l}\text { Judith Wagner, } \\
\text { MD }\end{array}$ & $\begin{array}{l}\text { Department of Neurology, } \\
\text { Kepler University Hospital, } \\
\text { Johannes Kepler University, } \\
\text { Linz, Austria }\end{array}$ & $\begin{array}{l}\text { Site } \\
\text { investigator }\end{array}$ & $\begin{array}{l}\text { Contributor } \\
\text { to the } \\
\text { GENERATE } \\
\text { registry }\end{array}$ \\
\hline $\begin{array}{l}\text { Robert } \\
\text { Weissert, MD }\end{array}$ & $\begin{array}{l}\text { Department of Neurology, } \\
\text { University of Regensburg, } \\
\text { Regensburg, Germany }\end{array}$ & $\begin{array}{l}\text { Site } \\
\text { investigator }\end{array}$ & $\begin{array}{l}\text { Contributor } \\
\text { to the } \\
\text { GENERATE } \\
\text { registry }\end{array}$ \\
\hline $\begin{array}{l}\text { Heinz Wiendl, } \\
\text { MD }\end{array}$ & $\begin{array}{l}\text { Department of Neurology } \\
\text { with Institute of } \\
\text { Translational Neurology, } \\
\text { University of Münster, } \\
\text { Münster, Germany }\end{array}$ & $\begin{array}{l}\text { Site } \\
\text { investigator }\end{array}$ & $\begin{array}{l}\text { Contributor } \\
\text { to the } \\
\text { GENERATE } \\
\text { registry }\end{array}$ \\
\hline $\begin{array}{l}\text { Brigitte } \\
\text { Wildemann, MD }\end{array}$ & $\begin{array}{l}\text { Molecular } \\
\text { Neuroimmunology } \\
\text { Group, Department of } \\
\text { Neurology, University of } \\
\text { Heidelberg, Heidelberg, } \\
\text { Germany }\end{array}$ & $\begin{array}{l}\text { Site } \\
\text { investigator }\end{array}$ & $\begin{array}{l}\text { Contributor } \\
\text { to the } \\
\text { GENERATE } \\
\text { registry }\end{array}$ \\
\hline $\begin{array}{l}\text { Karsten Witt, } \\
\text { MD }\end{array}$ & $\begin{array}{l}\text { Department of Neurology, } \\
\text { School of Medicine and } \\
\text { Health Sciences, University } \\
\text { of Oldenburg, Oldenburg, } \\
\text { Germany }\end{array}$ & $\begin{array}{l}\text { Site } \\
\text { investigator }\end{array}$ & $\begin{array}{l}\text { Contributor } \\
\text { to the } \\
\text { GENERATE } \\
\text { registry }\end{array}$ \\
\hline
\end{tabular}


Appendix 2 (continued)

\begin{tabular}{llll}
\hline Name & Location & Role & Contribution \\
\hline $\begin{array}{l}\text { Sigrid Wöpking, } \\
\text { MD }\end{array}$ & $\begin{array}{l}\text { Department of Neurology, } \\
\text { University Hospital, } \\
\text { Technische Universität } \\
\text { Dresden, Dresden, } \\
\text { Germany }\end{array}$ & $\begin{array}{l}\text { Site } \\
\text { investigator }\end{array}$ & $\begin{array}{l}\text { Contributor } \\
\text { to the } \\
\text { GENERATE } \\
\text { registry }\end{array}$ \\
$\begin{array}{llll}\text { Benjamin } \\
\text { Wunderlich, MD }\end{array}$ & $\begin{array}{l}\text { Charité - } \\
\text { Department of Neurology, } \\
\text { Berlin, Germany }\end{array}$ & $\begin{array}{l}\text { Site } \\
\text { investigator }\end{array}$ & $\begin{array}{l}\text { Contributor } \\
\text { to the } \\
\text { GENERATE } \\
\text { registry }\end{array}$ \\
\hline Lara Zieger, MD & $\begin{array}{l}\text { Department of Neurology, } \\
\text { Philipp University, } \\
\text { Marburg, Germany }\end{array}$ & $\begin{array}{l}\text { Site } \\
\text { investigator }\end{array}$ & $\begin{array}{l}\text { Contributor } \\
\text { to the } \\
\text { GENERATE } \\
\text { registry }\end{array}$ \\
\hline
\end{tabular}

\section{References}

1. Leypoldt F, Armangue T, Dalmau J. Autoimmune encephalopathies. Ann N Y Acad Sci. 2015;1338(1):94-114.

2. Graus F, Titulaer MJ, Balu R, et al. A clinical approach to diagnosis of autoimmune encephalitis. Lancet Neurol. 2016;15(4):391-404.

3. Dalmau J, Gleichman AJ, Hughes EG, et al. Anti-NMDA-receptor encephalitis: case series and analysis of the effects of antibodies. Lancet Neurol. 2008;7(12): 1091-1098.

4. Titulaer MJ, McCracken L, Gabilondo I, et al. Treatment and prognostic factors for long-term outcome in patients with anti-NMDA receptor encephalitis: an observational cohort study. Lancet Neurol. 2013;12(2):157-165.

5. Irani SR, Alexander S, Waters $\mathrm{P}$, et al. Antibodies to Kv1 potassium channel-complex proteins leucine-rich, glioma inactivated 1 protein and contactin-associated protein- 2 in limbic encephalitis, Morvan's syndrome and acquired neuromyotonia. Brain. 2010, 133(9):2734-2748.

6. Lai M, Huijbers MG, Lancaster E, et al. Investigation of LGI1 as the antigen in limbic encephalitis previously attributed to potassium channels: a case series. Lancet Neurol. 2010;9(8):776-785.

7. Irani SR, Michell AW, Lang B, et al. Faciobrachial dystonic seizures precede Lgil antibody limbic encephalitis. Ann Neurol. 2011;69(5):892-900.

8. Lancaster E, Martinez-Hernandez E, Dalmau J. Encephalitis and antibodies to synaptic and neuronal cell surface proteins. Neurology. 2011;77(2):179-189.

9. Irani SR, Pettingill P, Kleopa KA, et al. Morvan syndrome: clinical and serological observations in 29 cases. Ann Neurol. 2012;72(2):241-255.

10. Arino H, Gresa-Arribas N, Blanco Y, et al. Cerebellar ataxia and glutamic acid decarboxylase antibodies: immunologic profile and long-term effect of immunotherapy. JAMA Neurol. 2014;71(8):1009-1016.

11. Dalakas MC, Li M, Fujii M, Jacobowitz DM. Stiff person syndrome: quantification, specificity, and intrathecal synthesis of GAD65 antibodies. Neurology. 2001;57(5): 780-784.

12. Giometto B, Miotto D, Faresin F, Argentiero V, Scaravilli T, Tavolato B. Antigabaergic neuron autoantibodies in a patient with stiff-man syndrome and ataxia. J Neurol Sci. 1996;143(1-2):57-59.
13. Gresa-Arribas N, Arino H, Martinez-Hernandez E, et al. Antibodies to inhibitory synaptic proteins in neurological syndromes associated with glutamic acid decarboxylase autoimmunity. PLoS One. 2015;10(3):e0121364.

14. Dubey D, Britton J, McKeon A, et al. Randomized placebo-controlled trial of intravenous immunoglobulin in autoimmune LGI1/CASPR2 epilepsy. Ann Neurol. 2020;87(2):313-323

15. Dalakas MC, Rakocevic G, Dambrosia JM, Alexopoulos H, McElroy B. A doubleblind, placebo-controlled study of rituximab in patients with stiff person syndrome. Ann Neurol. 2017;82(2):271-277.

16. Hauser SL, Waubant E, Arnold DL, et al. B-cell depletion with rituximab in relapsingremitting multiple sclerosis. $N$ Engl J Med. 2008;358(7):676-688.

17. Trebst C, Jarius S, Berthele A, et al. Update on the diagnosis and treatment of neuromyelitis optica: recommendations of the Neuromyelitis Optica Study Group (NEMOS). J Neurol. 2014;261(1):1-16

18. Lee WJ, Lee ST, Byun JI, et al. Rituximab treatment for autoimmune limbic encephalitis in an institutional cohort. Neurology. 2016;86(18):1683-1691.

19. Nepal G, Shing YK, Yadav JK, et al. Efficacy and safety of rituximab in autoimmune encephalitis: a meta-analysis. Acta Neurol Scand. 2020;142(5):449-459.

20. Bien CG, Bien CI, Dogan Onugoren M, et al. Routine diagnostics for neural antibodies, clinical correlates, treatment and functional outcome. J Neurol. 2020;267(7): 2101-2114.

21. Nosadini M, Mohammad SS, Ramanathan S, Brilot F, Dale RC. Immune therapy in autoimmune encephalitis: a systematic review. Expert Rev Neurother. 2015;15(12): 1391-1419.

22. Abboud H, Probasco J, Irani SR, et al. Autoimmune encephalitis: proposed recommendations for symptomatic and long-term management. J Neurol Neurosurg Psychiatry. 2015;15(12):1391-1419.

23. Shin YW, Lee ST, Shin JW, et al. VGKC-complex/LGI1-antibody encephalitis: clinical manifestations and response to immunotherapy. J Neuroimmunol. 2013;265(1-2):75-81.

24. Arino H, Armangue T, Petit-Pedrol M, et al. Anti-LGI1-associated cognitive impairment: Presentation and long-term outcome. Neurology. 2016;87(8):759-765.

25. van Sonderen A, Thijs RD, Coenders EC, et al. Anti-LGI1 encephalitis: clinical syndrome and long-term follow-up. Neurology. 2016;87(14):1449-1456.

26. Irani SR, Gelfand JM, Bettcher BM, Singhal NS, Geschwind MD. Effect of rituximab in patients with leucine-rich, glioma-inactivated 1 antibody-associated encephalopathy. JAMA Neurol. 2014;71(7):896-900

27. Graus F, Saiz A, Dalmau J. GAD antibodies in neurological disorders - insights and challenges. Nat Rev Neurol. 2020;16(7):353-365.

28. Di Giacomo R, Deleo F, Pastori C, et al. Predictive value of high titer of GAD65 antibodies in a case of limbic encephalitis. J Neuroimmunol. 2019;337:577063.

29. Vasconcelos OM, Dalakas MC. Stiff-person syndrome. Curr Treat Options Neurol. 2003;5(1):79-90.

30. Tsiortou P, Alexopoulos H, Dalakas MC. GAD antibody-spectrum disorders: progress in clinical phenotypes, immunopathogenesis and therapeutic interventions. Ther Adv Neurol Disord. 2021;14:17562864211003486.

31. Hao W, Davis C, Hirsch IB, et al. Plasmapheresis and immunosuppression in stiff-man syndrome with type 1 diabetes: a 2-year study. J Neurol. 1999;246(8):731-735.

32. McKeon A, Robinson MT, McEvoy KM, et al. Stiff-man syndrome and variants: clinical course, treatments, and outcomes. Arch Neurol. 2012;69(2):230-238.

33. Mitoma H, Hadjivassiliou M, Honnorat J. Guidelines for treatment of immunemediated cerebellar ataxias. Cerebellum Ataxias. 2015;2:14

34. Jones AL, Flanagan EP, Pittock SJ, et al. Responses to and outcomes of treatment of autoimmune cerebellar ataxia in adults. JAMA Neurol. 2015;72(11):1304-1312.

35. Daif A, Lukas RV, Issa NP, et al. Antiglutamic acid decarboxylase 65 (GAD65) antibody-associated epilepsy. Epilepsy Behav. 2018;80:331-336.

36. Malter MP, Frisch C, Zeitler H, et al. Treatment of immune-mediated temporal lobe epilepsy with GAD antibodies. Seizure. 2015;30:57-63. 


\title{
Neurology \\ Neuroimmunology \& Neuroinflammation
}

\author{
Rituximab Treatment and Long-term Outcome of Patients With Autoimmune \\ Encephalitis: Real-world Evidence From the GENERATE Registry \\ Franziska S. Thaler, Luise Zimmermann, Stefan Kammermeier, et al. \\ Neurol Neuroimmunol Neuroinflamm 2021;8; \\ DOI 10.1212/NXI.0000000000001088
}

This information is current as of October 1, 2021

Updated Information \&

Services

References

Citations

Subspecialty Collections

Permissions \& Licensing

Reprints including high resolution figures, can be found at:

http://nn.neurology.org/content/8/6/e1088.full.html

This article cites 36 articles, 0 of which you can access for free at: http://nn.neurology.org/content/8/6/e1088.full.html\#\#ref-list-1

This article has been cited by 1 HighWire-hosted articles: http://nn.neurology.org/content/8/6/e1088.full.html\#\#otherarticles

This article, along with others on similar topics, appears in the following collection( $\mathrm{s}$ ):

All Immunology

http://nn.neurology.org//cgi/collection/all_immunology

Autoimmune diseases

http://nn.neurology.org//cgi/collection/autoimmune_diseases

Information about reproducing this article in parts (figures,tables) or in its entirety can be found online at:

http://nn.neurology.org/misc/about.xhtml\#permissions

Information about ordering reprints can be found online:

http://nn.neurology.org/misc/addir.xhtml\#reprintsus

Neurol Neuroimmunol Neuroinflamm is an official journal of the American Academy of Neurology.

Published since April 2014, it is an open-access, online-only, continuous publication journal. Copyright

Copyright (C) 2021 The Author(s). Published by Wolters Kluwer Health, Inc. on behalf of the American

Academy of Neurology.. All rights reserved. Online ISSN: 2332-7812.

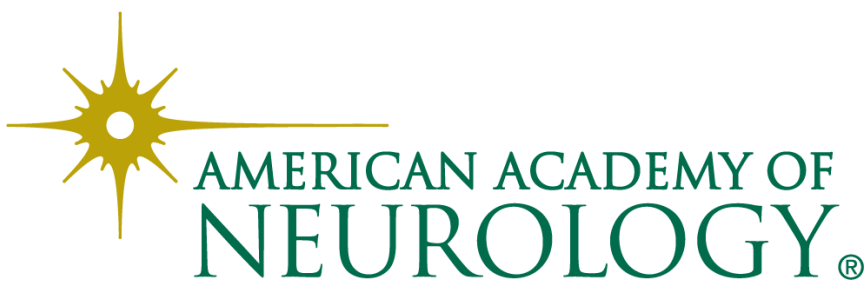

